\title{
A ESQUIZOFRENIA DE DIFERENÇA E REPETIÇÃO À LÓGICA DO SENTIDO
}

\author{
Filipe Ferreira ${ }^{1}$
}

\begin{abstract}
Resumo: $\mathrm{O}$ artigo se propõe a analisar a maneira em que Artaud, o esquizofrênico, estremece o pensamento de Deleuze ainda antes do Anti-Édipo (1972) e do seu encontro com Guattari. O projecto geral de Diferença e repetição (1968) estremece no preciso momento em que, na 13a série da Lógica do sentido (1969), Deleuze passa a admitir a "ameaça inicialmente imperceptível" de um não-sentido esquizofrênico e da espécie de destrutividade ou sem-fundo esquizofrênico dos corpos que pressupõe. É a partir deste ponto de vista que abordaremos como "o problema da esquizofrenia" tal como surge na Lógica do sentido está na origem de uma nova concepção de imanência no pensamento de Deleuze, da gênese do seu projecto crítico e clínico e, finalmente, de uma nova teoria do inconsciente que, apostando tudo numa suposta origem sexual da linguagem, reorienta a própria psicanálise na direcção de uma "psicanálise do sentido".
\end{abstract}

Palavras-chave: esquizofrenia; ontologia; linguagem; metafísica; imanência.

\begin{abstract}
We have opted here to analyze the way Artaud, the schizophrenic, shakes Deleuze"s thought before Anti-Oedipus (1972) and his encounter with Guattari, more specifically, in the transition from Difference and Repetition to the Logic of Sense. The overall project of Difference and Repetition (1968) trembles in the precise moment when, in the $13^{\text {th }}$ series of the Logic of Sense (1969), Deleuze begins to admit the "initially imperceptible threat" of a schizophrenic nonsense and the sort of destructivity or bodily schizophrenic sans fond it presupposes. It is from this point of view that we shall consider how the "problem of schizophrenia" such as it appears in the Logic of Sense is at the basis of a new conception of immanence in Deleuze"s thought, of his critical and clinical project and, finally, of a new theory of the unconscious which, wagering everything on a supposed sexual origin of language, reorients psychoanalysis itself in the direction of a "psychoanalysis of sense".
\end{abstract}

Keywords: schizophrenia; ontology; language; metaphysics; immanence.

1.

Se perguntarmos do que consiste o projecto crítico de Diferença e repetição, seremos levados ao que Deleuze define como a imagem do pensamento e, mais especificamente, ao problema de como destruir esta imagem. ${ }^{2} \mathrm{O}$ que isto nos diz, primeiro, é que uma filosofia verdadeiramente crítica é a que cria, no interior do pensamento, a destruição de todo e qualquer pressuposto que, acrítica ou dogmaticamente, pré-determinaria a natureza do próprio acto de pensar; e, segundo, que é agora no interior deste movimento de destruição que se passará a propor uma concepção deste acto na sua gênese enquanto gê-

1 Doutor em Filosofia pela Universidade Nova de Lisboa.

2 cf. o capítulo 3, "A imagem do pensamento", DELEUZE, G. Diferença e repetição. Lisboa: Relógio d'Água, 2000, doravante DR. 
nese de si mesmo no próprio pensamento. É neste sentido que falamos de um movimento de destruição, ele mesmo produzido no interior do pensamento: é ao criar a destruição da imagem do pensamento que se criam as condições críticas para o começo do próprio pensar no pensamento, para uma verdadeira criação entendida nos termos de um acto de pensar que cria a gênese de si mesmo em si mesmo. ${ }^{3}$ Trata-se, assim, de um movimento de destruição que nos leva ao cerne do que Deleuze entende por imanência: é agora na imanência do movimento destrutivo que o pensamento se afirma como "pensamento sem imagem", ${ }^{4}$ mas é também sem jamais transcender este movimento e as condições críticas que estabelece que se garante uma verdadeira criação entendida nos termos da gênese do acto de pensar no próprio pensamento. Imanência absoluta do pensamento: um acto de pensar cujo começo é absolutamente imanente a si mesmo, um acto de pensar que só garante esta imanência absoluta do pensamento na medida em que jamais deixa de destruir a imagem do pensamento, criando a gênese de si mesmo em si mesmo na imanência desta destruição.

E como pensa Deleuze este movimento de destruição enquanto condição crítica para o começo do acto de pensar no pensamento? Se não pensamos nos restringir a Diferença e repetição é porque, antes mesmo do Anti-Édipo e do encontro com Guattari, parecem-nos existir duas respostas distintas a esta questão, uma em Diferença e repetição e outra na Lógica do sentido. Afinal, se na Lógica do sentido Deleuze atribui à destrutividade sofrida pelo esquizofrênico, por Artaud, uma especificidade própria, se, por outras palavras, ele passa a distinguir esta destrutividade como definindo uma espécie de destruição que não garante de todo as condições críticas para a gênese do acto de pensar no pensamento, não é evidente que, pelo menos em relação a Diferença e repetição, onde esta distinção não é operativa, é o próprio movimento de destruição que se complica? Como pensar a destruição da imagem do pensamento se, a partir da Lógica do sentido, existem duas concepções distintas desta destruição, dois movimentos de destruição que diferem em natureza? Se só um deles garante as condições críticas para a gênese do acto de pensar no pensamento? Se o que se afigura é a necessidade de problematizar ambas as destrutividades e os seus movimentos de destruição respectivos, de pensar a destrutividade que garantiria as condições críticas para uma verdadeira criação partindo do pressuposto que existe uma outra espécie de destrutividade que não as garante de todo?

Talvez a este respeito, não existam páginas mais elucidativas do que as de Diferen-

\footnotetext{
3 "As condições de uma verdadeira crítica e de uma verdadeira criação são as mesmas: destruição da imagem de um pensamento que se pressupõe a si próprio, génese do acto de pensar no próprio pensamento". DR, p.240.

4 "Ela [a crítica radical da imagem do pensamento] encontraria a sua diferença ou o seu verdadeiro começo não num acordo com a Imagem pré-filosófica, mas numa luta rigorosa contra a Imagem, denunciada como não-filosofia. Ela encontraria, assim, a sua repetição autêntica num pensamento sem Imagem, mesmo que fosse à custa das maiores destruições". DR, p.229-30.
} 
ça e repetição onde, num abrir e fechar de olhos, Deleuze passa de uma concepção da destruição da imagem do pensamento pensada nos termos do que define como um "exercício transcendente das faculdades," onde "cada faculdade é levada ao ponto extremo do seu desregramento, ponto em que ela é como que presa de uma tríplice violência, violência daquilo que a força a exercer-se, daquilo que ela é forçada a apreender e daquilo que só ela tem o poder de apreender", ${ }^{5}$ à sugestão que o exemplo privilegiado desta violência se encontraria na correspondência entre Rivière e Artaud. Apesar de toda a radicalidade crítica de Diferença e repetição, existirá legitimidade especificamente clínica para, numa página, se pensar a destruição da imagem do pensamento nos termos da referida violência e da espécie de "acordo discordante" entre as faculdades que dela resultaria tal como Kant o pensa no exercício do sublime, e, logo na outra que a segue, se passar à correspondência entre Rivière e Artaud, a uma concepção desta violência assente no desabamento sofrido pelo esquizofrênico ${ }^{6}$ Não se deu um salto gigantesco, muito maior do que as pernas? Não seria necessário pressentir, como Deleuze acabará por fazer na Lógica do sentido, que, afinal, "mudamos de elemento, entramos numa tempestade?"7 Que ainda que a correspondência entre Rivière e Artaud seja de facto uma destruição "exemplar" da imagem do pensamento (em especial pela distinção entre o pensamento como algo "inato" ou, pelo contrário, "genital"») ainda assim é demasiado rápido se pensar em "acordos", ainda que discordantes, quando o que se encontra em jogo são "os debates de uma vida convulsiva, a noite de uma criação patológica referente aos corpos?"9

E como passa Deleuze a distinguir a destrutividade sofrida por Artaud na Lógica do sentido? Ora, através da extraordinária análise da "tentativa anti-gramatical [de Artaud] contra Lewis Carroll" ${ }^{\prime 10}$ na $13^{\text {a }}$ série: é justamente este confronto que é inteiramente ausente de Diferença e repetição. Mas como é esta tentativa pensada por Deleuze? Se é na Lógica do sentido que este confronto se apresenta como absolutamente incontornável, qual o aspecto específico a esta lógica que leva Deleuze a sugerir uma diferença de

\begin{abstract}
5 DR, p.245.
6 "O uso transcendente das faculdades é, propriamente falando, um uso paradoxal, que se opõe a que o seu exercício se dê sob a regra do senso comum. Além disso, [do ponto de vista deste uso transcendente] o acordo das faculdades só pode ser produzido como um acordo discordante, pois cada uma só comunica à outra a violência que a coloca na presença da sua diferença e da sua divergência com todas. Kant foi o primeiro a mostrar o exemplo de um tal acordo pela discordância com o caso da relação entre imaginação e do pensamento, tal como eles se exercem no sublime". DR, p.249-50. A página que segue começa assim: "Nada é mais exemplar do que a troca de cartas entre Jacques Rivière e Antonin Artaud..." DR, p.251.
\end{abstract}

7 DELEUZE, G. Lógica do sentido. São Paulo: Perspectiva, 2006, p.85, doravante LS.

8 "Pensar é criar, não há outra criação, mas criar é, antes de tudo, engendrar, 'pensar' no pensamento. Eis porque Artaud opõe, no pensamento, a genitalidade ao inatismo [Descartes como exemplo privilegiado], mas, igualmente, à reminiscência [Platão]". DR, p.252.

9 Ibidem.

10 cf. "L"Arve e I"Aume, tentative anti-grammaticale contre Lewis Carroll" em ARTAUD, A. Antonin Artaud: Oeuvres. Paris: Gallimard, p.917. 
natureza entre duas espécies de destrutividades? Anunciemos que se trata do "problema mais geral da Lógica do sentido", o da relação entre o sentido e o não-sentido, da insistência por parte de Deleuze numa espécie de "relação original intrínseca" ou "modo de copresença" entre o sentido e o não-sentido, e isto ao ponto de se assumir que, longe do não-sentido se opor ao sentido numa relação simples de exclusão, é justamente a partir do não-sentido que se garante a doação de sentido, a gênese do próprio sentido. ${ }^{11}$ Mas o que terá esta gênese que ver com o esquizofrênico, com Artaud? Simplesmente, que o esquizofrênico revela uma espécie de não-sentido que não opera esta doação, que não garante a gênese do sentido. Mais, que se o esquizofrênico sofre um não-sentido que difere em natureza do que se encontra em modo de copresença com sentido, é porque o seu sofrimento pressupõe uma destruição cuja natureza terá de ser abordada na sua especificidade própria. Enfim, voltemo-nos para as palavras de Deleuze, para um dos momentos mais belos de toda a sua obra, o momento onde o próprio admite que passou rápido demais pela esquizofrenia, por Artaud:

A ameaça [do não-sentido esquizofrênico] é primeiramente imperceptível; mas bastam alguns passos para nos apercebermos de uma falha aumentada e que toda a organização de superfície já desapareceu, atirada para uma ordem primária terrível. O não-sentido já não dá o sentido: devorou tudo. Acreditávamos primeiro permanecer no mesmo elemento ou num elemento vizinho [do não-sentido]. Percebemos agora que mudamos de elemento, que entramos numa tempestade. Acreditávamos ainda estar entre as menininhas e as crianças: encontramo-nos agora numa loucura irreversível. Acreditávamos estar no ponto culminante de pesquisa literária, na mais alta invenção das linguagens e das palavras; encontramo-nos agora nos debates de uma vida convulsiva, na noite de uma criação patológica referente aos corpos. É por isso que o observador deve permanecer atento: é pouco suportável, sob o pretexto das palavras-valise, por exemplo, ver misturar as histórias infantis, as experimentações poéticas e as experiências da loucura. ${ }^{12}$

11 "Quando dizemos que o não-sentido diz o seu próprio sentido, queremos dizer que o sentido e o não-sentido têm uma relação específica que não pode copiar a relação do verdadeiro e do falso, ou seja, que não pode ser concebida simplesmente nos termos de uma relação de exclusão. É justamente este o problema mais geral de uma Lógica do sentido: de que serviria elevarmo-nos da esfera do verdadeiro à do sentido se fosse só para encontrar entre o sentido e o não-sentido uma relação análoga à do verdadeiro e do falso? ... A Lógica do sentido se vê necessariamente determinada a colocar entre o sentido e o não-sentido um tipo original de relação intrínseca, um modo de copresença". LS, p.71. E em relação à doação: "O não-sentido é ao mesmo tempo o que não tem sentido, mas que, enquanto tal, opõe-se à ausência de sentido, operando a doação de sentido. E é isto que é preciso entender por nonsense". LS, p.74.

12 LS, p.85. As palavras-valise são uma espécie específica de palavra esotérica que se refere às palavras esotéricas disjuntivas, ou seja, às palavras que, não deixando de se designarem a si próprias como casa vazia e ocupante sem lugar em ambas as séries, "operam uma ramificação infinita das séries coexistentes e recaem, ao mesmo tempo, sobre as palavras e os sentidos, os elementos silábicos e semiológicos (disjunção). É a função ramificante ou a síntese disjuntiva que dá a definição real da palavra-valise". LS, 
Que sintamos que Deleuze escreveu estas linhas pensando também em si próprio, como se a ameaça do não-sentido esquizofrênico lhe fosse inicialmente imperceptível, e isto ao ponto de também ele ter acreditado poder permanecer no mesmo elemento do não-sentido ou um elemento vizinho, é algo que a própria velocidade com que passa em Diferença e repetição de Kant a Artaud nos ajudaria, mais uma vez, a realçar. Mas convém detalharmos este quadro e isto pelo seguinte facto: Diferença e repetição já inclui muito mais do que o esboço do que Deleuze virá a conceber nos termos de uma Lógica do sentido; inclui as suas teses centrais, ${ }^{13}$ ainda que em momento algum Deleuze admita tanto a diferença de natureza de um não-sentido que não opera a doação de sentido como a especificidade da destrutividade sofrida pelo esquizofrênico. Diríamos até que em relação à própria Lógica do sentido pressente-se que as séries iniciais foram escritas sem que Deleuze antevisse a $13^{\text {a }}$ série, o confronto entre Artaud e Carroll. Talvez a evidência mais clara do que dizemos seja a necessidade que Deleuze sente na $26^{\text {a }}$ série de retomar as páginas inicias da Lógica do sentido onde tudo começa com a invenção de uma "superfície metafísica" ou "extra-ser do ser" que Deleuze atribui ao estoicismo, enfim, com a nova distribuição ontológica atribuída por Deleuze aos estóicos entre duas dimensões do ser, em profundidade (Cronos) e à superfície (Aion), e a maneira em que passa a ser nos termos desta nova distribuição que enquadra o "debate obscuro" sobre o "simulacro" ou a "profundidade das coisas" atribuído essencialmente a Platão e a Lucrécio. ${ }^{14}$ Se nestas pá-

p.50. Realce-se, no entanto, que ao abordar o confronto entre Artaud e Carroll, Deleuze não deixa de conceber uma palavra-valise de outra ordem, justamente a que é criada por uma "Ioucura irreversível" e que remete a um não-sentido de outra natureza, que já não opera a doação de sentido: "Uma menina pode cantar 'Pimpanicalho' [Pimpanicaille], um artista pode escrever 'fumioso' [frumious], um esquizofrénico dizer 'perspendicaz' [perspendicace]. Não é sério confundir a canção de Babar e os gritos-sopro de Artaud, "Ratara ratara ratara Atara tatara rana Otara otara katara..." LS, p.86.

13 No que se refere à inclusão das teses essenciais da "lógica do sentido" em Diferença e repetição, ver em especial a crítica ao sexto postulado da imagem dogmática do pensamento, "o da proposição ou da designação, postulado que recolhe os precedentes [postulados] e se encadeia com eles (a forma da designação é apenas a forma lógica da recognição)." DR, p.261. Esta crítica é inteiramente retomada na Lógica do sentido, em particular através da concepção do que Deleuze ali define como o "círculo da proposição" e da concepção do sentido tanto como uma "quarta dimensão da proposição" como também e, do ponto de vista genético, a dimensão irredutível que "anima um modelo interior a priori da proposição". cf. a importantíssima $3^{a}$ série da Lógica do sentido sobre a proposição.

14 Pelo menos no que se refere ao sentido enquanto concebido como um "acontecimento ideal" que tanto insiste na proposição como é atribuído logicamente ao objecto ou estado de coisas, concepção esta que, ainda que Diferença e repetição não se refira ao estoicismo neste contexto, virá na Lógica do sentido a ser atribuída à filosofia da linguagem inaugurada pelos estóicos, é patente que Deleuze já supõe em Diferença e repetição o que virá a definir como uma superfície metafisica ou dimensão extra-ser do ser: "Este complexo [o sentido enquanto insistência na proposição e atributo lógica da própria coisa] é um acontecimento ideal. É uma entidade objectiva, mas da qual não se pode nem dizer que ela existe em si mesma: ela insiste, ela subsiste, tendo um quase-ser, um extra-ser, o mínimo comum aos objectos reais, possíveis e mesmo impossíveis." DR, p.264. Por outro lado, no que se refere ao ser em profundidade, que Deleuze concebe em Diferença e repetição nos termos das sínteses passivas do hábito profundo, existe uma frase que indica claramente que Deleuze também atribuí a concepção desta profundidade das coisas aos estóicos: "Uma das grandes contribuições do estoicismo foi ter mostrado que todo o signo é signo de um presente, do ponto de vista da síntese passiva, em que o passado e o futuro são precisamente apenas dimensões do próprio presente DR, p.152. O "debate obscuro" em torno da profundidade das coisas atribuído a Platão é um tema central tanto a Diferença e repetição como à Lógica do sentido, em DR ver por exemplo, p.221 ou p.243. Em relação a Lucrécio, ver o segundo capítulo no apêndice da Lógica do sentido, "Lucrécio e o Simulacro". 
ginas inicias Deleuze divide a profundidade entre o que se submete à acção transcendente da Ideia platónica (cópia) e o que se esquiva a esta acção (simulacro), estando Aion ou o devir-ilimitado de um presente que se divide em si mesmo em duas direcções opostas, a do passado e do futuro, dependente do próprio devir-louco da profundidade e da constituição do simulacro agora à superfície, por que nos diz Deleuze na $26^{\mathrm{a}}$ série que "no começo deste estudo podíamos fingir que os dois [Aion e o simulacro ou devir-louco da profundidade] se prolongavam estreitamente", que, "quanto muito, havia entre eles [somente] uma mudança de orientação, [onde] com o Aion o devir-louco das profundidades subia à superfície?"15 $\mathrm{O}$ que estará na origem deste "fingimento"? Tratar-se-à realmente de um fingimento? Mas por que indica Deleuze na frase que se segue que o que se encontra em jogo é, afinal, uma aprendizagem, e isto na medida em que "aprendemos que esta mudança de orientação, esta conquista da superfície, implicava diferenças radicais sob todos os aspectos?"16 Mas o que foi "aprendido" entre a 2a e a 26 série? Que "diferenças radicais" são estas?

Se dissermos que se trata da diferença radical entre dois não-sentidos, o que assumimos é que se, já não se admite que Aion e o devir-louco das profundidades se "prolonguem estreitamente", é porque se "aprendeu" que o problema da ascensão do simulacro à superfície (da "mudança de orientação") é muitíssimo mais complexo. E como repercute esta complexidade sobre as páginas iniciais da Lógica do sentido, onde a ascensão do simulacro à superfície é concebida nos termos de um "prolongamento" do devir-louco das profundidades no devir-ilimitado de Aion? Ora, antes de mais, que não existe "prolongamento". Mas por quê? Porque enquanto enquadrado nos termos da diferença radical entre dois não-sentidos, é o próprio devir-louco das profundidades, ou seja, a concepção do simulacro que se esquiva à acção da Ideia platónica em profundidade que, reformulada, passará a corresponder mais especificamente ao esquizofrênico, ao seu sofrimento e à espécie de não-sentido que não opera a doação de sentido. Não se deixará, portanto, de conceber a ascensão do simulacro à superfície nos termos de um não-sentido que, em modo de copresença com o sentido, opera a doação sentido: o que se especifica é que, se já não é possível admitir a concepção desta ascensão nos termos de um prolongamento, é porque tudo começa com uma "ordem primária terrível", com o devir-louco das profundidades pensado agora mais especificamente nos termos de um sem-fundo esquizofrênico dos corpos. E como pensará Deleuze a tal "mudança de orientação", a constituição do simulacro à superfície se, em profundidade, o simulacro nos remete agora ao esquizofrênico, a Artaud, enquanto "caso exemplar" de um esquivar incessante da acção transcendente das Ideias platónicas? Ainda que analisaremos mais adiante a abordagem proposta por

15 LS, p.169.

16 Ibidem - os itálicos são nossos. 
Deleuze a este problema na Lógica do sentido, consideremos o que, do ponto de vista da $13^{\text {a }}$ série e da diferença radical entre não-sentidos que estabelece, uma abordagem a este problema teria de assegurar: falamos de uma mudança de orientação pensada nos termos de uma espécie de transmutação de não-sentidos, de um movimento de ascensão que, transmutando o não-sentido do esquizofrênico na espécie de não-sentido que se encontra em modo de copresença com o sentido, garante a doação de sentido, o não-sentido que opera esta doação e, enquanto tal, tanto a constituição do simulacro à superfície como o acontecimento genético do próprio sentido.

Voltemos às condições críticas para uma verdadeira criação: o que dizer agora destas condições do ponto de vista desta nova condição crítica, a de uma mudança de orientação entre o profundo sem-fundo e a superfície pensada mais especificamente nos termos de uma transmutação de não-sentidos? Antes de mais, realcemos que, já em Diferença e repetição, a gênese do acto de pensar no pensamento pressupõe o que a Lógica do sentido define nos termos de um modo de copresença entre o sentido e não-sentido. ${ }^{17}$ Nestes termos, o que já se pressupõe é justamente uma relação original intrínseca entre o sentido e o não-sentido como condição crítica para um acto de pensar que cria a gênese de si mesmo em si mesmo. Se perguntarmos como esta relação se relaciona com a destruição da imagem do pensamento em Diferença e repetição, teremos de voltar ao exercício transcendente das faculdades, à violência que coloca cada faculdade na presença da sua diferença e da sua divergência radical com todas as outras: é do ponto de vista deste exercício e de uma violência comunicada às faculdades que Deleuze concebe tanto a destruição da imagem do pensamento como o "prolongamento" desta destruição na gênese do acto de pensar no pensamento. Que o seja é evidente pela teoria da Ideia proposta por Deleuze em Diferença e repetição: se a Ideia percorre a fenda que se abre entre as faculdades no exercício transcendente, ${ }^{18}$ o que isto confirma é que a própria Ideia pressupõe tanto a

\footnotetext{
17 "Há somente uma palavra que se diz a si própria e o seu sentido: precisamente, a palavra não-sentido, abraxas, snark ou blituri. E se o sentido é necessariamente um não-sentido para o uso empírico das faculdades, inversamente, os não-sentidos, tão frequentes no uso empírico, são como o segredo do sentido para o observador consciente, cujas faculdades tendem para um limite transcendente". DR, p.262. O que também já se encontra presente em Diferença e repetição é o lugar privilegiado que Deleuze atribuirá a Lewis Carroll na Lógica do sentido, e isto por ser ele quem encena os paradoxos constitutivos do sentido em modo de copresença com o não-sentido: "Lewis Carroll fez um compêndio maravilhoso de todos estes paradoxos". DR, p.264.
}

18 A fenda ela mesma se refere ao que, desde Descartes, divide o sujeito entre um "eu penso" (puro) e um "eu sou" (indeterminado) e que, a partir de Kant, será mais especificamente concebida como a forma pura tanto do tempo como da interioridade do sujeito. É mais precisamente ao longo das bordas que se formam ao longo desta fenda que circulam as Ideias: "A Ideia retoma os três aspectos do Cogito: o $E u$ sou como existência indeterminada; o tempo como forma sob a qual essa existência é determinável, o $E u$ penso como determinação [ideal]. As Ideias são exactamente os pensamentos do Cogito, as diferenciais do pensamento. E assim como o Cogito remete para um Eu fendido - fendido de um extremo ao outro pela forma do tempo que o atravessa -, é preciso dizer das Ideias que elas formigam nas fendas, que elas emergem constantemente nos rebordos das fendas, que emergem constantemente compondo-se de mil maneiras". DR, p.286. Será nos termos de Ideias que nascendo do interior da própria fenda no Eu e que formam os "pensamentos do Cogito" que Deleuze proporá um "inconsciente do pensamento puro": "Toda a proposição da consciência implica um inconsciente do pensamento puro, que constitui a esfera do sentido e onde se regressa ao infinito". DR, p.263. 
violência ou destruição comunicada a cada faculdade, levando-as ao seu limite extremo, como o acto de pensar que nasce na imanência desta destruição. Mas se agora perguntarmos o que a Ideia nos diz sobre o modo de copresença entre o sentido e o não-sentido, verificamos que o confirma:

\begin{abstract}
A Ideia, que percorre todas as faculdades, não se reduz, todavia, ao sentido. É que, por sua vez, ela também é não-sentido; e não há qualquer dificuldade em conciliar este duplo aspecto pelo qual a Ideia é constituída de elementos estruturais que não têm sentido por si mesmos, mas que constituem o sentido de tudo o que ela produz. ${ }^{19}$
\end{abstract}

Ou seja, é justamente por assumirmos um exercício transcendente que, comunicando uma violência às faculdades, rouba-lhes a possibilidade de um acordo no senso comum enquanto cogitatio natura universalis, que teremos de supor elementos estruturais que, transcendendo o modelo de uma concordância das faculdades de um sujeito pensante sobre um objecto qualquer, não têm sentido. Ainda assim, não deixa de ser com base nestes elementos que se constitui uma Ideia, no que confirma, primeiro, que Diferença e repetição já concebe a relação original intrínseca entre o sentido e o não-sentido ao supor que é a partir de elementos estruturais que não têm sentido que a Ideia produz o seu sentido; ${ }^{20}$ e, segundo, que se é de uma Ideia que falamos, ou seja, do acto de pensar que a criou, que ao criar a gênese de si mesmo em si mesmo o que este acto pressupõe é o não-sentido, os elementos estruturais que não têm sentido em si mesmos mas que adquirem-no na medida em que, criando-se o começo do pensar no pensamento, cria-se uma Ideia e o sentido que lhe pertence por direito.

Ainda que a centralidade dada em Diferença e repetição à teoria da Ideia não se repita na Lógica do sentido, ${ }^{21}$ não deixa de ser evidente o que se complicaria passando-se a admitir a especificidade de um não-sentido esquizofrênico: afinal, como se garantiria a criação da Ideia a partir de elementos estruturais que não têm sentido em si mesmos se o que agora se apresenta é uma diferença de natureza inerente ao próprio não-sentido, a "ameaça inicialmente imperceptível" de um não-sentido a partir do qual nada nasce, nem sentido, nem pensamento, nem Ideia? Trata-se de uma pergunta que Diferença e repetição não considera por não determinar a especificidade do não-sentido esquizofrênico e da

19 DR, p.262.

20 "O sentido é como a Ideia que se desenvolve nas determinações sub-representativas". DR, p.262.

$21 \mathrm{E}$ isto pelo que Deleuze entende por uma Ideia estar de certo modo pressuposto: "O problema pode muito bem ser recoberto pelas soluções, nem por isso deixa de subsistir na Ideia que o refere às suas condições e organiza a génese das próprias soluções ... "Problemático" qualifica precisamente as objectividades ideias. Kant foi, sem dúvidas, o primeiro a fazer do problemático não uma incerteza passageira mas o próprio objecto da Ideia e com isto também um horizonte indispensável a tudo o que acontece ou aparece". LS, p.57-58. 
destrutividade que lhe é inerente (ou seja, pela ameaça lhe ser "imperceptível") mas que, por outro lado, não deixará de ser, como anunciamos, respondida na Lógica do sentido na medida em que se acrescenta uma nova condição crítica às que Diferença e repetição estabelece para uma verdadeira criação: a condição crítica de uma transmutação de não-sentidos através da qual se garante a espécie de não-sentido que, em modo de copresença com o sentido, opera a doação de sentido e, enquanto tal, a espécie de elementos estruturais de não-sentido doadores de sentido na origem de uma Ideia tal como Diferença e repetição a propõe. Mas, mais uma vez, antes de considerarmos como, de facto, esta transmutação é pensada por Deleuze na Lógica do sentido, não descolemos por agora destas condições e da maneira em que esta nova condição crítica, a de uma transmutação de não-sentidos, levará Deleuze a uma reformulação extraordinária do que entende por estas condições num sentido geral.

O que temos em mente é a introdução, na Lógica do sentido, de uma dimensão propriamente clínica ao problema que em Diferença e repetição é apresentado em termos críticos. Ou seja, se a partir da Lógica do sentido já não nos parece legítimo falar exlusivamente em termos críticos das condições para a gênese do acto de pensar no pensamento é porque, para além de críticas, estas condições passarão a ser concebidas por Deleuze como clínicas. Trata-se, por outras palavras, da problemática crítica e clínica que, não por acaso, é justamente na $13^{\mathrm{a}}$ série da Lógica do sentido que Deleuze a define pela primeira vez:

O problema [do não-sentido esquizofrênico] é o da clínica, isto é, do deslize de uma organização [da linguagem] para outra ou da formação de uma desorganização progressiva e criadora. O problema é também o da crítica, isto é, da determinação dos níveis diferenciais em que o não-sentido muda de figura, a palavra-valise de natureza, a linguagem inteira de dimensão. ${ }^{22}$

É agora nos termos do não-sentido esquizofrênico que a crítica e a clínica se encontram, que as condições críticas para uma verdadeira criação passam a ser definidas crítica e clinicamente: criticamente por ser em termos críticos que se distinguem "níveis diferencias" e se estabelece o nível específico que garante as condições para uma verdadeira criação; clinicamente por ser em termos clínicos que se determinam as condições de passagem de um nível a outro e, enquanto tal, a garantia do nível diferencial específico na origem de uma verdadeira criação. Ou seja, é nos termos do não-sentido esquizofrênico que se determina criticamente tanto a diferença de natureza entre dois não-sentidos como também o porquê do não-sentido que opera a doação de sentido constituir o nível diferencial que garante as condições críticas para a gênese do acto de pensar no pensamento; mas 
é também nos termos do não-sentido esquizofrênico que se constitui o problema clínico de determinar a natureza da destrutividade especificamente esquizofrênica, de questionar como esta destrutividade poderá ser transmutada de maneira a garantir o não-sentido de superfície, o que opera a doação de sentido e, enquanto tal, as condições (agora críticas e clínicas) para a gênese do acto de pensar no pensamento.

Em suma, é do ponto de vista de uma Lógica do sentido e do seu problema central, a relação entre o sentido e o não-sentido, que Deleuze passa a formular a distinção crítica e clínica entre dois não-sentidos que diferem em natureza. Para além do que acabamos de ver, que, nos termos desta profundidade, terá de se admitir uma nova complexidade inerente ao projecto crítico de destruir a imagem do pensamento, ela mesma ausente de Diferença e repetição, o que também teremos de admitir é a maneira em que a referida distinção crítica e clínica repercute sobre o próprio projecto ontológico de Diferença e repetição na medida em que, radicalizando a distinção ontológica entre o devir-louco das profundidades e a concepção de uma superfície metafísica enquanto mínimo comum tanto à interioridade dos corpos como à exterioridade do ser, Deleuze introduz uma nova concepção ontológica na sua filosofia, a do devir-louco das profundidades pensado mais especificamente nos termos da esquizofrenia. Assim, e sublinhando em Diferença e repetição que a "esquizofrenia não é somente um facto humano mas uma possibilidade do pensamento que apenas se revela enquanto tal na abolição da imagem do pensamento," 23 é como se Deleuze admitisse que o problema é, como dissemos, muitíssimo mais complexo: é pela esquizofrenia revelar (e isto "exemplarmente" ou primeiramente) o que se entende pela destruição implicada na abolição da imagem do pensamento, que a própria "possibilidade de pensamento" concedida à esquizofrenia passará na Lógica do sentido a ser sujeita a metamorfoses radicais de maneira a afirmar-se enquanto passível deste "possível", no que só confirma, mais uma vez, que a partir da Lógica do sentido deixa de existir um prolongamento imediato entre a esquizofrenia, a destruição da imagem do pensamento e a gênese do acto de pensar no pensamento cujas condições (agora críticas e clínicas) são estabelecidas pelo movimento de destruição.

2.

E qual o eixo que permitirá a Deleuze responder à maneira em que a problemática crítica e clínica, tal como é definida a partir da $13^{\mathrm{a}}$ série, desafia o projecto crítico, ontológico e metafísico de Diferença e repetição? Falamos essencialmente da aposta de Deleuze numa concepção de "vida" assente na sexualidade: ${ }^{24}$ é através do problema geral

23 DR, p.252.

24 "Uma psicanálise deve ser de dimensões geométricas antes de ser de anedotas históricas. Pois a vida, a própria sexualidade, estão na organização e orientação destas dimensões, antes de estar nas matérias geradoras e nas formas engendradas". LS, p.95. 
referente às relações entre a sexualidade e a linguagem que a Lógica do sentido proporá uma teoria do inconsciente que responde ao desafio de assegurar o nível diferencial na origem de uma verdadeira criação, ou seja, a tal relação intrínseca entre o sentido e o não-sentido como condição crítica e clínica para a gênese do acto de pensar no pensamento. Mas o que terá a sexualidade que ver com a nova distinção ontológica operante na Lógica do sentido entre o sem-fundo esquizofrênico e a superfície extra-ser ou metafísica do ser? E se é através da sexualidade que se garantirá algo tão estranho como uma transmutação de não-sentidos e das destrutividades que lhes são inerentes (uma abordagem ao problema crítico e clínico), como se renovará as relações entre a sexualidade e a linguagem de maneira a responder a este problema?

Que seja o eixo linguagem/sexualidade que Deleuze vise desde o início (ou seja, logo a partir da $13^{\text {a }}$ série) é evidente até pela maneira em que, segundo ele, o problema central da psicanálise é justamente o do sentido, em particular, o de responder ao problema de como garantir a transmutação de não-sentidos e das suas destrutividades, a relação original intrínseca entre o sentido e o não-sentido como condição crítica e clínica para a gênese do acto de pensar no pensamento. Mas ainda longe da "crítica à razão psicanalítica” proposta com Guattari no Anti-Édipo, o que se pretende na Lógica do sentido é reorientar a psicanálise de maneira a fazer com que ela ecoe tanto o problema geral da Lógica do sentido como o problema que surge, no interior desta lógica, através da gênese do projecto crítico e clínico de Deleuze. Não nos surpreenderá assim que Deleuze sinta a necessidade de sugerir esta reorientação logo na $13^{\text {a }}$ série, primeiro, criticamente, ao notar que uma "má psicanálise", "misturando tudo", não opera a distinção crítica e clínica entre ambos os não-sentidos e as suas respectivas destruições, mas também, segundo, agora positivamente, através da sugestão que, enquanto enquadrada de maneira a responder ao projecto geral da Lógica do sentido, é a própria psicanálise que se afirmará como uma "psicanálise do sentido". ${ }^{25}$

Assim, o que se pede agora é que, partindo da linguagem do esquizofrênico ou

25 No que se refere à crítica: "Podemos encontrar na criança uma 'posição' esquizóide antes de ela se ter elevado ou conquistado a superfície [Deleuze refere-se à superfície extra-ser ou metafísica]. Na própria superfície podemos sempre encontrar pedaços esquizóides, uma vez que ela tem precisamente por sentido organizar e estender elementos vindos das profundidades. Nem por isso é menos execrável e deplorável misturar tudo, seja a conquista da superfície na criança, seja a falência da superfície no esquizofrénico ... Podemos sempre fazer da obra de Lewis Carroll uma espécie de conto esquizofrénico ... Uma má psicanálise tem duas maneiras de se enganar, ou por acreditar descobrir matérias idênticas que encontram-se forçosamente em outras partes ou formas análogas que operam falsas diferenças. É ao mesmo tempo que se deixa escapar o aspecto clínico psiquiátrico [a destrutividade] e o aspecto crítico literário [relação sentido/não-sentido]". LS, p.95. E no que se refere à concepção da psicanálise como "psicanálise do sentido": "A psicanálise não pode se contentar em designar casos, manifestar histórias ou significar complexos. A psicanálise é psicanálise do sentido. Ela é geográfica antes de ser histórica. Ela distingue países diferentes. Artaud não é Carroll nem a Alice, Carroll não é Artaud, Carroll nem é a Alice. Antonin Artaud aprofunda a criança numa alternativa extremamente violenta de acordo com as duas linguagens em profundidade, de paixão e acção corporais ... Carroll espera a criança, de acordo com a sua linguagem do sentido incorporal: ele a espera no ponto e no momento em que a criança deixou as profundidades do corpo materno ... São países diferentes, dimensões diferentes e sem relação ... Artaud e Carroll não se reencontram; só o comentador pode mudar de dimensão, e eis a sua grande fraqueza, o sinal que não habita dimensão alguma". LS, p.95-96. 
a maneira em que Artaud "aprofunda a criança numa alternativa extremamente violenta", ${ }^{26}$ mostremos como as metamorfoses inerentes à posição sexual no seu todo (fase pré-genital, genital e formação do "complexo de Édipo") são pensadas por Deleuze como confirmando a conhecida tese de uma origem sexual da linguagem ou desta origem enquanto concebida do ponto de vista de uma Lógica do sentido. Foquemos na linguagem do esquizofrênico: é ao longo de dois pólos que Deleuze aborda esta linguagem. No primeiro pólo, pólo que, seguindo a distinção proposta por Louis Wolfson entre uma linguagem materna e outra estrangeira do próprio esquizofrênico, ${ }^{27}$ Deleuze concebe como "materna", falamos essencialmente do despedaçamento da palavra em pedaços, da sua "[decomposição] em sílabas, letras e sobretudo consoantes que agem directamente sobre o corpo, penetrando-o e mortificando-o". ${ }^{28}$ Trata-se assim de uma explosão da palavra que é essencialmente física ("Toda a palavra é física, afecta imediatamente o corpo"), ${ }^{29}$ onde "os seus elementos fonéticos tornam-se singularmente contundentes", ou seja, onde "a palavra talvez conserve um certo poder de designação mas apreendido como vazio, um certo poder de manifestar mas apreendido como indiferente, uma certa significação mas apreendida como "falsa", , 30 "perdendo, em todos os casos, o seu sentido, isto é, a sua capacidade de recolher ou exprimir um efeito incorporal distinto das acções e paixões do corpo, um acontecimento ideal distinto da sua própria efectuação no presente". "A1 "A palavra deixou de exprimir um atributo do estado de coisas, os seus pedaços confundem-se com qualidades sonoras insuportáveis, invadem o corpo onde formam uma mistura, um novo estado de coisas, como se fossem eles próprios alimentos venenosos, ruidosos e excrementos encaixados ... "Nesta paixão, ao efeito da linguagem substitui-se uma palavra linguagem-afecto: Toda a escrita é MERDA". ${ }^{32}$

Passando ao segundo polo, jamais se transcende o não-sentido esquizofrênico: longe de se pretender recuperar o sentido, é como se, passando a procurar uma resposta à explosão da palavra, à paixão dolorosa do corpo directamente afectado por esta decomposição, fosse a própria destruição da palavra que se procurasse levar até ao seu absoluto,

\footnotetext{
26 cf. nota anterior.
}

27 Deleuze voltará a Wolfson, "o estudante de línguas dementes", no seu último livro, Crítica e clínica (cf. cap. 2, "Louis Wolfson, ou o procedimento", DELEUZE, G. Crítica e clínica. São Paulo: 34, 2008). Na Lógica do sentido, cf. p.86. Tanto quanto sabemos, ainda está para ser determinado o que representa este regresso a Wolfson na Crítica e Clínica do ponto de vista do problema da linguagem no pensamento de Deleuze e, especialmente, do ponto de vista do abandono - a partir do Anti-Édipo e do seu encontro com Guattari - da sua aposta evidente na Lógica do sentido na sexualidade e nas relações entre a sexualidade e a linguagem.

28 LS, p. 90.

29 Ibidem.

30 Ibidem.

31 Ibidem.

32 LS, p.90-91. 
um pouco como se, procurando transpor ou "transpassar" o limite ou "muro" de sofrimento imposto pela língua materna do esquizofrênico, ${ }^{33}$ fosse o próprio sofrimento, a destruição e o não-sentido enquanto não-sentido abissal, que nenhum sentido "doa", que se desejasse afirmar como um facto absoluto (facto cuja "facticidade" é agora interior à desrazão, no lado de Fora ou absolutamente Outro ao que estrutura um "ser no mundo"). Trata-se da criação de uma acção que converta o corpo destruído no pólo da língua materna num corpo absoluto, o corpo verdadeiramente humano, "inato" ao homem de que tanto insiste Artaud enquanto realidade absoluta do lado Duplo da própria existência tal como a conhecemos, encarnados que estamos nos corpos que nos encontramos, corpos deformados, de um magnetismo deficiente, "organismos" de que pouco mais há a dizer a não ser que cagam, dormem, acordam com bocas acres e azedas, enfim, que desestruturam por completo "o equilíbrio entre a produção mágica e a produção automática" ${ }^{34}$ $\mathrm{O}$ "procedimento" 35 que leva a linguagem à exigência desta conversão jamais deixará de nos comover, precisamente por nos levar à necessidade de uma resposta, ou seja, de uma acção (ou criação) por parte do esquizofrênico que responda à destruição abissal, involuntária, a que o seu corpo é sujeito no pólo da língua materna e da paixão ou sofrimento de ser sujeito às forças informuladas que, para além do próprio corpo, também despedaçam a palavra e a linguagem no seu todo (uma "ordem primária terrível"):

Para o esquizofrênico, trata-se menos, portanto, de recuperar o sentido do que de destruir a palavra, de conjurar o afecto ou de transformar a paixão dolorosa do corpo em acção triunfante, a obediência em comando, sempre nesta profundidade abaixo da superfície escavacada. O estudante de línguas [Wolfson] dá o exemplo dos meios através dos quais as explosões dolorosas da palavra da língua materna são convertidas em acções relativas às línguas estrangeiras. Vimos há pouco que aquilo que feria provinha dos elementos fonéticos que afectam as partes articuladas ou desarticuladas do corpo. $\mathrm{O}$ triunfo não pode ser agora obtido a não ser pela criação de palavras-sopros [mots-souffles] ou palavras-uivo [mots-cris], onde todos os valores literais, silábicos e fonéticos são substituídos por valores exclusivamente tónicos e não escritos, aos quais corresponde um corpo glorioso como uma nova dimensão do corpo esquizofrênico, um organismo sem partes que faz tudo por insuflação, inspiração, evaporação, transmissão fluídica (o corpo superior ou corpo sem órgãos de Antonin Artaud). ${ }^{36}$

33 A noções de "transpassagem e de "muro" se referem a uma terminologia utilizada por Deleuze-Guattari no Anti-Édipo, cf. por exemplo, p.182-184.

34 "O Homem-Árvore (carta a Pierre Loeb)" em ARTAUD, A. Eu, Antonin Artaud. Lisboa: Assírio \& Alvim, 2007, p.156.

35 Que teria de ser analisado em muito mais detalhe nos termos do capítulo que Deleuze dedica a Wolfson na Crítica e clínica.

36 LS, p.91. 
Compreende-se assim que, pelo menos para Deleuze, é através de uma análise à linguagem do esquizofrênico, que não nos cansaremos de qualificar como extraordinária, que o próprio concebe duas polaridades distintas como constitutivas do sem-fundo esquizofrênico mas também do próprio corpo do esquizofrênico nesta profundidade abissal. Que seja também esta análise que esteja na origem da revisão que opera ao teatro de terror kleiniano é evidente: se a linha (ou Spaltung profundo como Deleuze o define na Lógica do sentido $)^{37}$ que divide as profundidades dos corpos nada tem que ver com a distinção entre o bom e o mau, a introjecção e projecção de objectos parciais bons e maus ou, se quisermos, com a famosa distinção entre "o seio bom e o mau", é porque o que está na origem desta divisão é a distinção entre dois corpos distintos do esquizofrênico, o corpo fragmentado, despedaçado no pólo da língua materna, e o corpo superior, pleno, absoluto e sem órgãos, no pólo da língua estrangeira. Notamos também o esforço que Deleuze faz de maneira a enquadrar ambos estes corpos ou pólos esquizofrênicos no teatro proposto por Klein, primeiro ao sugerir que "a teoria psicanalítica tem a tendência de negligenciar a importância e o dinamismo do tema corpo sem órgãos", ${ }^{38}$ e, depois, ao sugerir que, se é possível enquadrar este corpo na teoria psicanalítica, é por existir uma diferença de natureza entre um sadismo anal e uretral, ou seja, pela espécie de plenitude pressuposta pelo corpo sem órgãos, segundo Deleuze, ser passível de ser concebida especificamente nos termos de uma espécie de integridade líquida, "no sentido em que o princípio líquido assegura a soldadura dos pedaços num bloco", ${ }^{39}$ o tal bloco indecomponível das palavras-sopro e palavras-uivo enquanto concebido "psicanalíticamente" nos termos de um sadismo uretral. Enfim, já sabemos que toda esta história de associar a esquizofrenia ao sadismo, anal ou uretral, tanto faz, todo este esforço de integrar a extraordinária análise da linguagem do esquizofrênico, com os seus dois pólos, no quadro geral da teoria psicanalítica, saíra pela janela fora a partir do Anti-Édipo. ${ }^{40}$ Mas se não é aqui que analisaremos

37 "A fissura de superfície nada tem de comum com o Spaltung profundo". LS, p.94.

38 cf. nota 3 da $27^{\text {a }}$ série sobre a oralidade.

39 Ibidem.

40 Ainda que, note-se, o Anti-Édipo também se refira ao corpo sem órgãos como supondo um princípio líquido: "Mas um puro fluido, em estado livre e sem cortes, está em vias de deslizar sobre um corpo pleno". DELEUZE-GUATTARI, O Anti-Édipo. São Paulo: Ed. 34, p.20, doravante A-E. Seja como for, no Anti-Édipo deixa-se de formular a distinção entre os dois pólos esquizofrénicos nos termos do sadismo, abandonando-se por inteiro o esforço de articular ambos estes pólos ao teatro de terror cujo "quadro inesquecível foi Klein quem pintou". Aliás, é justamente Klein a primeira visada na crítica que o Anti-Édipo dirige à psicanálise em geral, não só (como a Lógica do sentido de certo modo já o indica) "por ter negligenciado o estudo dos fluxos e os declare sem importância", cf. A-E, p.55) mas essencialmente por "extrapolado" a relação papá-mamã-criança (cf. o primeiro paralogismo da psicanálise, a da "triangulação", para a crítica a Klein agora ao longo deste eixo, A-E, p.101) da produção desejante na sua síntese conectiva, o de uma "produção de produção" (importantíssima para uma concepção do desejo enquanto produção precisamente pelo paradoxo que envolve, o de produzir produção). Mas mesmo no que se refere à concepção fluídica ou líquida do corpo sem órgãos, vale a pena acrescentar que é só realmente na referida síntese, a de conexão, que este corpo se afirma enquanto tal. Ou seja, a partir da segunda síntese do inconsciente, a disjuntiva ou de distribuição, a superfície já não é líquida mas intensiva (enquanto superfície de inscrição). Mas é a síntese final do inconsciente no Anti-Édipo (a conjuntiva ou de consumo) que, referindo-se 
este texto nem o porquê de Deleuze passar a considerar a sexualidade (tal como a psicanálise a concebe) como um conjunto de problemas mal colocados, é por insistirmos na outra direcção, a que Deleuze abandonará no Anti-Édipo após o seu encontro com Guattari, ou seja, a direcção que vai de Diferença e repetição à Lógica do sentido na qual Deleuze se vira para sexualidade para responder a um problema inerente à Lógica do sentido, a do não-sentido e a sua relação com o sentido, sendo assim levado a propor uma reorientação da própria psicanálise, que não deixa de ser singular e mais uma evidência do seu génio, como "psicanálise do sentido".

Retomemos: é agora a posição sexual que surge como intermediária entre as linguagens do esquizofrênico e de superfície, o que nos diz que esta posição, por outras palavras, encontra-se entre ambos os não-sentidos. Dito assim, torna-se evidente que é através dela que se opera a transmutação de não-sentidos e das destruições que lhes são inerentes, sendo mais precisamente nestes termos que Deleuze aposta nas relações entre a sexualidade e a linguagem para responder ao problema crítico e clínico constituído no interior da Lógica do sentido. Mas como?

Notemos que, para Deleuze, é a passagem da posição esquizóide-paranóide (com os seus dois pólos) à maníaco-depressiva que define a primeira etapa da formação da linguagem. Por quê? Porque se o sem-fundo é ruidoso, um sistema sonoro composto pelos "estalos, os rangidos, crepitações, explosões, ruídos explodidos dos objectos [parciais] internos, mas também pelos gritos-sopros inarticulados do corpo sem órgãos [no outro pólo]", ${ }^{41}$ o que a reorganização da tensão originária entre o Id e o ego através da mediação do superego sublinha é o surgimento de uma Voz vinda do alto, "voz que ama e dá segurança, que ataca e repreende, que se lamenta por estar ferida, ou que se retira e cala". ${ }^{42} \mathrm{Já}$ Freud insistia na origem acústica do superego: trata-se "da voz de Deus como superego, aquela que proíbe sem que saibamos o que é proibido, pois não a apreenderemos a não ser pela sanção". ${ }^{43}$ Note-se que não se trata de maneira alguma de roubar uma voz ao esquizofrênico, mas de uma distinção de natureza entre um sistema sonoro pré-vocal, onde "a voz materna deve ser urgentemente decomposta em ruídos fonéticos literais e recomposta

a quantidades intensivas e "a algo da ordem do sujeito" (A-E, p.30), parece se referir ao segundo pólo da linguagem esquizofrénica, formada por palavras-sopro, palavras-uivo.

41 LS, p.197.

42 LS, p.198. Pressupomos aqui a segunda revisão que Deleuze opera ao teatro de terror kleiniano: ao contrário de Klein que assume que a relação bom/mau se refere aos próprios objectos internos, para Deleuze esta relação é como que verticalizada na medida em que o bom objecto se refere agora uma dimensão inteiramente distinta, a do alto, tratando-se também de um objecto completo e não parcial. Ou seja, para Deleuze o surgimento do superego sublinha uma reorientação fundamental da vida psíquica, tal como a psicanálise o propõe, mas só na medida em que são agora os dois pólos do sem-fundo esquizofrénico (que Klein não propõe) que são mediados desde o alto, através de um objecto completo e bom retirado nas alturas (o que, como dizemos, "verticaliza" a relação entre o bom e o mau). cf. a $27^{a}$ série, sobre a oralidade, para a dupla revisão que Deleuze opera ao teatro de terror kleiniano.

43 Ibidem. 
em blocos inarticulados"44 (o "procedimento" de Wolfson), e outro sistema sonoro, agora vocal, onde surge uma voz do alto que, ao contrário da linguagem do esquizofrênico, já dispõe de todas as dimensões da linguagem organizada. Ou seja, a voz já "denota", tanto o bom objecto como os objectos parciais introjectados, ela também já "“"manifesta” as variações emocionais da pessoa completa (voz que ama, ataca, etc.)”, mas também já "significa" "todos os conceitos e classes que estruturam o domínio da preexistência". ${ }^{45}$

Mas a voz apresenta assim as dimensões de uma linguagem organizada sem poder ainda tornar apreensível o princípio de organização segundo o qual seria, ela mesma, uma linguagem. Ficamos assim fora do sentido e longe dele, desta vez num pré-sentido das alturas [mas já não num não-sentido esquizofrênico] ... Pois, em verdade, ainda que designe o objecto perdido, não se sabe o que ela designa; não se sabe o que significa, uma vez que significa a ordem das pré-existências; não se sabe o que manifesta, uma vez que manifesta o retirar-se para o interior do seu princípio ou silêncio. ${ }^{46}$

Compreende-se assim que a organização da linguagem sobre a superfície física e sexual tem uma origem comum no surgimento do sistema vocal informado pelo bom objecto, retirado e perdido nas alturas. Falamos assim de uma pré-compreensão da linguagem por parte da criança que funda a própria linguagem enquanto organizada segundo os diferentes aspectos da posição sexual. Ou seja, o que dizemos é que a criança extrai da voz os elementos formadores da linguagem. Mais, que é segundo a distinção entre as três fases referentes à posição sexual (pré-genital, genital, complexo de Édipo) e correspondentes formas de seralização (e sínteses), que ela o faz. É indesmentível a influência de Lacan no modo em que Deleuze concebe esta "extracção". ${ }^{47}$ No que se refere aos elementos formadores, falamos de fonemas, morfemas e semantemas: por um lado, assume-se que, em relação à voz do alto, "a criança recorta os elementos das diferentes ordens"; 48 e, por outro, que, fazendo-o, ela assume o risco de "dar-lhes uma função pré-linguística em relação ao conjunto e aos diferentes aspectos da posição sexual". ${ }^{49} \mathrm{Ou}$ seja, ainda

\footnotetext{
44 LS, p.199.
}

45 LS, p.198.

46 Ibidem.

47 "Embora os trabalhos de Lacan tenham um alcance muito mais vasto, tendo renovado completamente o problema das relações sexualidade/linguagem, incluem também indicações aplicáveis à complexidade desta segunda etapa [referente à extracção dos elementos formadores da linguagem nos termos da posição sexual] - indicações seguidas e desenvolvidas por alguns dos seus discípulos". LS, p.237.

48 LS, p.237.

49 Ibidem. 
que se pergunte "em que medida podemos ligar assim os fonemas às zonas erógenas, os morfemas com o estágio fálico e os semantemas com a evolução de Édipo e o complexo da castração", responde-se encontrando em Lacan (e, em especial, no trabalho de Serge Leclaire $)^{50}$ as tais indicações aplicáveis à complexidade envolvida nesta formação inicial da linguagem sobre a superfície física e sexual. Enfim, não entraremos nos detalhes: se os fonemas se ligam à fase pré-genital é pelo movimento do libido referente a cada zona erógena ser "marcado por uma "letra" que, ao mesmo tempo, traçaria o seu limite e subsumiria as imagens ou os objectos de satisfação [autoerótica]"; ${ }^{51}$ enquanto que, em relação à organização genital, focamos na maneira em que os fonemas formam elementos mais complexos, como se a concordância fálica ou a conexão das zonas erógenas em torno do falo gerasse um "conjunto ou sequências de letras assegurando a imagem do falo na sua convergência e continuidade". ${ }^{52} \mathrm{O}$ que estas sequências definiriam é a construção das primeiras palavras esotéricas por parte da criança, enquanto que, na fase derradeira da posição sexual, estas palavras adquiriam um novo valor na medida em que comporiam séries independentes que entrariam em divergência umas com as outras, uma série sendo a significante e outra a significada, onde passaríamos a realçar as relações de ressonância ou formação de sínteses disjuntivas entre elas: é só aqui que "a palavra esotérica se torna ela mesma palavra-valise", ${ }^{53}$ e desempenha "o papel de um semantema de acordo com a tese de Lacan segundo a qual o falo de Édipo e da castração é um significante que não anima a série correspondente [edipiana] sem surgir repentinamente na série precedente [pré-edipiana], onde também circula". ${ }^{54}$

"Em suma, vamos da letra fonemática à palavra esotérica como morfema, depois à palavra-valise como semantema". ${ }^{55}$ Assim se extraem os elementos formadores da linguagem da voz do alto, ou pré-sentido. Mas note-se: falamos dos elementos formadores da linguagem e não da linguagem ela mesma. Assim, permanecemos num domínio pré-linguísitico, "que não tem outra referência além da sexual, como se a criança aprendesse a falar sobre o seu próprio corpo [a superfície física e sexual]". ${ }^{56} \mathrm{Ou}$ seja, ainda não estamos no domínio do sentido, ainda que esteja tudo apostos para tal: começamos com o não-sentido ou infrassentido do sem-fundo esquizofrênico, tanto com o despedaçamento da palavra em elementos fonéticos agressores como com a recomposição ela mesma es-

50 cf. nota 6 e 7 da $32^{\text {a }}$ série sobre as diferentes espécies de séries.

51 Ibidem.

52 LS, p. 238.

53 Ibidem.

54 LS, p.239.

55 Ibidem.

56 Ibidem. 
quizofrênica da palavra na forma indecomponível de palavras-grito, uivo, enfim, com o corpo sem órgãos de Artaud enquanto concebido sonoramente, musicalmente diríamos, como ruído; assistimos depois ao surgimento da voz do alto, à reorganização da tensão originária entre o Id e ego através da mediação do bom objecto do alto, voz da qual a criança extrai os tais elementos formadores da linguagem, os fonemas projectados sobre zonas erógenas, os morfemas ou as primeiras palavras esotéricas da criança e também os semantemas, onde estas palavras passam a compor séries independentes, significantes e significadas, do ponto de vista de uma outra espécie de síntese, a disjuntiva, que garante a "ressonância" entre séries divergentes (as palavras-valise). É como se, aprendendo a falar sobre o seu corpo, a criança extraísse da voz do alto ou de um pré-sentido os elementos formadores da linguagem que, ainda que organizem a linguagem ao longo das três etapas de organização sexual e das suas respectivas séries e sínteses, não garantem de todo a gênese do sentido a partir do não-sentido. Falamos assim de outra espécie não-sentido, entre o não-sentido esquizofrênico e o de superfície, um não-sentido que mais parece estar numa relação de cossentido com o próprio sentido, mas isto só na medida em que a história não acaba aqui, sendo mais particularmente do ponto de vista da última metamorfose do inconsciente, a que assegura a tal relação intrínseca entre o sentido e o não-sentido, que atribuímos às primeiras palavras esotéricas e valise da criança o estatuto de um "cossentido". 57

3.

Viremo-nos então para esta metamorfose. No desdobramento referente à posição sexual tudo começa com as "boas intenções da criança" (fase pré-edipiana) e tudo acabará mal com a formação do "complexo" (fase edipiana). Mas se a história não acaba aqui é porque, segundo Deleuze, a distinção entre as intenções da criança e como a história acaba (castração da mãe, morte do pai, morte por castração da criança) não deve ser colocada nos termos de uma oposição simples entre a intenção e o resultado da acção. E por quê? Porque não se trata de todo de uma oposição entre duas acções mas de uma certa metamorfose do estatuto da acção em geral. Por um lado, a intenção não se refere a uma acção determinada, mas ao conjunto das imagens sobre a superfície física e sexual (voltaremos adiante ao que se entende pela categoria objectal "imagem"). Por outro lado, o resultado já não distinguirá esta ou aquela acção mas se referirá a tudo o que pode acontecer ou, se quisermos, a uma concepção transcendental na medida em que define os limites possíveis da afectibilidade (ou paixão) e da acção da criança. Mas o que este "por um lado" e "por outro" sublinham é uma espécie de cisão ou disjunção temporal (antes e depois)

57 "A organização da superfície física ainda não é sentido: ela é, ou antes, ela será cossentido. Isto é: quando o sentido for produzido sobre uma outra superfície, haverá também este sentido". LS, p.240. Enfim, é só realmente do ponto de vista da última metamorfose do inconsciente e da relação original entre o sentido e o não-sentido que o não-sentido referente à posição sexual se afirma como "cossentido". 
da própria acção entre a sua intenção original e o seu resultado final, sendo nos termos da mesma que Deleuze concebe, originalmente, o que define como a última metamorfose do inconsciente. Segundo o próprio, enquanto concebido no seu estatuto transcendental como "tudo o que pode acontecer", o resultado da acção já não se refere à superfície física e sexual, mas a uma nova superfície, desta vez metafísica, e isto na medida em que é sobre uma superfície metafísica que a acção é projectada enquanto tudo o que pode acontecer (o resultado): ou seja, "por um lado, [temos] a imagem inteira da acção sobre uma superfície física, onde ela aparece como desejada e encontra-se determinada sob as espécies de reparação [do corpo da mãe] e evocação [do pai enquanto objecto retirado, perdido]; por outro lado, o resultado no seu todo sobre uma superfície metafísica, onde a acção aparece como produzida e não desejada, determinada sob as espécies de assassínio [do pai] e de castração [da mãe]". ${ }^{58}$

Pode-se dizer que a acção inteira projectou-se sobre uma dupla tela, uma constituída pela superfície sexual e física, a outra por uma superfície metafísica ou "cerebral". Em suma, a intenção como categoria edipiana não opõe em absoluto uma acção determinada a uma outra, esta acção desejada, aquela obtida. Pelo contrário, ela toma o conjunto de toda a acção possível e divide [este conjunto] em dois, projecta-o sobre duas telas e determina cada lado de acordo com as exigências necessárias de cada tela. ${ }^{59}$

O que representa esta dupla projecção do ponto de vista pulsional? Segundo Deleuze, a necessidade de supor uma nova pulsão, desta vez, a pulsão de morte propriamente dita. Ainda que formulada no quadro geral da teoria freudiana, trata-se - já Diferença e repetição o analisava num detalhe que Deleuze preferiu não repetir na Lógica do senti$d o^{60}$ - de uma nova concepção da pulsão de morte desta vez “deleuziana”. Para Deleuze, é mais precisamente o que Freud chama de dessexualização, a espécie de energia neutra, deslocável, susceptível de fazer a ascendência das pulsões sexuais perder-se no que Freud concebia como a pulsão de morte, que constitui o eixo central de uma nova concepção da pulsão de morte. Deste novo ponto de vista, é como se Deleuze recriminasse Freud por já ter oferecido tudo o que seria necessário para propor uma experiência de morte no incons-

58 LS, p.214.

59 Ibidem. Ter-se-ia de determinar que espécie de interpretação do "mito" garante a Deleuze esta conclusão assente na concepção de uma metamorfose do estatuto da acção em geral. A este respeito, José Gil sugere a espécie de leitura (e que resulta de "uma colagem de Hölderlin e Nietzsche") que estaria na origem da insistência por parte de Deleuze na divisão do conjunto da acção ao longo de duas telas, uma física e outra metafísica. cf. GIL, J. O imperceptível devir da imanência. Lisboa: Relógio d’Água: 2008, nota 27, p.112.

60 cf. DR, p.199-203. Pelo menos no que se refere à enegria dessexualizada, neutra e deslocável, na Lógica do sentido esta análise repete-se através de uma nota, cf. nota 3 da 29a série. 
ciente (que Freud rejeita), mas por não levar a sério o que o próprio oferece ao insistir, primeiro, numa concepção de morte que repete o modelo materialista comum (a morte como matéria animada), e, segundo, no modelo dualista das pulsões onde a morte é pensada em oposição à vida (e que está na origem do primeiro aspecto). Pelo menos enquanto concebido nos termos do inconsciente, a morte para Deleuze nada tem que ver com a matéria inanimada mas com uma experiência que dessexualiza o inconsciente; se esta experiência não se opõe à vida, é na medida em que está na origem da cisão ou disjunção entre as duas telas que referimos ainda há pouco, a superfície física e a metafísica: ou seja, é justamente através da formação do "complexo" que divide o conjunto da acção, projectando-o sobre duas telas (intenção e resultado), que, por um lado, a superfície física é dessexualizada e, por outro, a energia neutra e deslocável libertada através da própria dessexualização da superfície física projectada sobre uma outra tela, desta vez metafísica. Assim, e ao contrário do que supõe Freud, longe de se referir à morte ou à concepção da morte segundo o modelo da matéria inanimada, para Deleuze a pulsão de morte está na origem da constituição de uma nova superfície, desta vez metafísica, e, enquanto tal, tanto na origem de uma nova dimensão do inconsciente como também - e paradoxalmente - de uma afirmação de vida.

Consideremos em mais detalhe, e ainda de um ponto de vista pulsional, o porquê de Deleuze entender que a pulsão de morte é uma afirmação de vida. Falamos de um terceiro aspecto na análise desta pulsão (para além da dessexualização da superfície física e sexual e consequente projecção da energia dessexualizada sobre uma nova tela, metafísica): a tese que nos diz que a pulsão de morte opera uma contraefectuação da destrutividade implicada nas pulsões destruidores do sem-fundo esquizofrênico. Falamos aqui de como Deleuze propõe na Lógica do sentido a transmutação das destrutividades implicadas em cada um dos não-sentidos, a do sem-fundo e a de superfície. O que anunciamos, primeiro, é que é nos termos de uma contraefectuação que ele a pensa, mas também, segundo, e agora do ponto de vista das condições críticas e clínicas, que é mais precisamente a destrutividade implicada na pulsão de morte propriamente dita que está na origem de uma verdadeira criação. Responder-se-à que em Diferença e repetição já era este o caso, que, por outras palavras, Deleuze já associava a sua versão da pulsão de morte ao que aí é concebido como as condições críticas (mas não críticas e clínicas) para uma verdadeira criação. Certamente não seremos nós a desmenti-lo: mas não deixa de ser igualmente patente que em Diferença e repetição Deleuze não sente a necessidade de pensar a sua versão da pulsão de morte como operando uma contraefectuação. Mais uma vez, responder-se-à que, ainda que não o faça, não deixa de ser evidente que a pressupõe: afinal, se a pulsão de morte se refere à outra faceta da morte (tão bem elaborada por Blanchot), onde o que se encontra em jogo é uma experiência de dessubjectivação onde o sujeito é destituído do poder morrer, de se apropriar do acontecimento da sua própria morte, não 
é evidente que esta experiência já pressupõe o que Deleuze virá a conceber na Lógica do sentido nos termos de uma contraefectuação? Não é justamente o poder de me apropriar da minha morte, de efectuar essa morte no meu corpo, e que me leva ao tal modelo de morte informado pela matéria inanimada, que é "contraefectuado"? Mais uma vez, não deixaremos de responder afirmativamente, ainda que seja necessário salientar, de passagem, que esta concepção de morte (a de um "morrer" mais profundo do que a própria morte) e da "pulsão" a que lhe está atrelada informa um "ponto de obscuridade central" a todo o pensamento de Deleuze, e isto ainda mais extremadamente a partir do momento em que se passa a assumir que a pulsão de morte contraefectua a destrutividade esquizofrênica... ${ }^{61}$ Mas não é a análise deste "ponto" que nos interessa neste momento: o que procuramos é ainda assim algo bem menos obscuro, mais rápido, tanto na medida em que nos parece evidente como também por se restringir ao que nos interessa aqui, a relação entre as destrutividades do sem-fundo e de superfície.

E, então, qual a novidade introduzida no pensamento de Deleuze através da insistência da sua parte em associar à pulsão de morte uma operação de contraefectuação? Ora, se é só na Lógica do sentido que Deleuze passa a conceber esta operação é porque o que Diferença e repetição não concebe de todo é o sem-fundo pensado segundo o esquizofrênico e a sua destruição. É justamente por Diferença e repetição não conceber a ameaça inicialmente imperceptível de uma destrutividade de outra natureza, ela mesmo esquizofrênica, que, neste texto, não se sugere de todo o que se virá a propor na Lógica do sentido: que é mais precisamente sobre as pulsões destruidoras do sem-fundo que a pulsão de morte opera uma contraefectuação, ou seja, que o que a contraefectuação contraefectua é a destrutividade implicada nestas pulsões (a destrutividade do esquizofrênico) numa destruição de outra natureza, a que é referente agora ao segundo aspecto ou figura da morte (a morte ou morrer impessoal) tal como é definido por Blanchot. ${ }^{62}$ Enfim, que seja este de facto o caso é evidente até pela espécie de tipologia pulsional que Deleuze propõe na Lógica do sentido: se as pulsões sexuais só se libertam ou ganham uma ascendência ao longo das três fases que compõem ou definem a posição sexual, entender-se-à também que, na última metamorfose, a dessexualização de todo o inconsciente não deixará de despertar as pulsões destruidoras do sem-fundo, de fazer ambas as superfícies, a física e a metafísica, incorrer os perigos de uma derrocada, "onde o fim reencontra o

\footnotetext{
61 "Ponto de obscuridade central [referente às duas figuras da morte] que não cessa de colocar [em questão] o problema das relações do pensamento com a esquizofrenia..." LS, p.215.

$62 \mathrm{Na}$ Lógica do sentido, é curioso notar que Deleuze introduz a noção de contraefectuação sem ainda referir que é mais especificamente sobre as pulsões destruidoras do sem-fundo esquizofrénico que elas actuam. Assim, é como se Deleuze nada mais fizesse do que acrescentar esta noção ao quadro geral referente à análise da pulsão de morte já elaborado em Diferença e repetição (referimo-nos aqui à $21^{a}$ série, sobre o acontecimento). É só na série que se segue (sobre a porcelana e o vulcão) que Deleuze passa a sublinhar que é sobre as pulsões destruidoras do sem-fundo que a pulsão de morte actua, contraefectuando as pulsões destruidoras em pulsão de morte e transmutando uma destrutividade noutra.
} 
ponto de partida e a pulsão de morte as pulsões destruidoras do sem-fundo". ${ }^{63}$ É agora ao contraefectuar estas pulsões destruidoras em pulsão de morte, enfim, ao transmutar ou converter uma destrutividade noutra, que se assegurará ambas as superfícies. Mas não deixa, por isso mesmo, de ser evidente que o que se encontra em jogo na última metamorfose do inconsciente é a destrutividade do esquizofrênico, que se Diferença $e$ repetição não concebia esta destrutividade na sua especificidade própria, também não avançava com a tese que a pulsão de morte contraefectua as pulsões destruidoras, no que nos parece sublinhar a necessidade específica que Deleuze sente em avançar com a noção de contraefectuação na Lógica do sentido e o porquê dela não surgir antes em Diferença e repetição. Mas o que também se esclarece, e talvez de uma maneira até mais clara na Lógica do sentido do que em Diferença e repetição, é o porquê da pulsão de morte ser paradoxalmente afirmativa da própria vida: é que, segundo Deleuze na Lógica do sentido, o modelo de morte pressuposto pelas pulsões destruidoras esquizofrênicas é a morte que se modela na imagem da matéria inanimada, enquanto que a pulsão de morte, referindo-se como se refere à experiência de uma dessexualização do inconsciente, pressuporia um outro modelo que, contraefectuando as pulsões destruidoras do sem-fundo, também contraefectuaria a efectuação da morte atribuída a estas pulsões e, enquanto tal, faria da espécie de destruição referente à pulsão de morte a "matéria intensiva" (entendida nos termos da energia dessexualizada) de uma afirmação radical de vida. ${ }^{64}$

Mas falemos de ainda outro ponto de vista, o objectal: o que consideramos deste ponto de vista são as sucessivas metamorfoses a que o simulacro do sem-fundo será sujeito até constituir-se à superfície, não simplesmente a física referente à posição sexual mas também a metafísica, o que confirma a nova complexidade pressuposta pela ascensão do simulacro à superfície. Segundo Deleuze (na Lógica do sentido), o simulacro refere-se mais especificamente aos objectos parciais introjectados e projectados, ou, se quisermos, ao pólo da língua materna do esquizofrênico onde as palavras são despedaçadas em elementos fonéticos essencialmente agressores e devoradores (uma oralidade anal). Neste sentido, o segundo pólo deste sem-fundo, referente ao corpo sem orgãos ou à reconstituição da palavra esquizofrênica na nova sonoridade indecomponível de palavras-sopro,

63 LS, p.215.

64 Que Deleuze associe as pulsões destruidoras ao modelo de morte comum, informado pela imagem da matéria inanimada, é notório na medida em que é nos termos de uma morte pessoal, minha, etc., (ou seja, o primeiro aspecto da morte tal como Blanchot a concebe) que a pensa: "O mesmo se dá com a morte: o eu narcísico a olha de dois lados, segundo as figuras [da morte] descritas por Blanchot - a morte pessoal e presente, que dilacera e "contradiz" o eu, abandona-o às pulsões destruidoras das profundidades e aos golpes do exterior; mas também a morte impessoal e infinitiva, que "distancia" o eu, fazendo-o soltar as singularidades que retinha, elevando-o à pulsão de morte sobre a outra superfície em que "morre-se", em que não se cessa e não se acaba de morrer". LS, p.230. Note-se, no entanto, que a partir do Anti-Édipo e do seu encontro com Guattari, Deleuze passará a rejeitar por completo a ideia que a destruição a que o esquizofrénico é sujeito se refere ao primeiro aspecto da morte, a morte como "minha" e informada pela matéria inanimada. Um novo modelo de morte, desta vez impessoal, será proposto para o esquizofrénico e a "sua" destruição: a catatonia, o que complicará tudo... "É a esquizofrenia catatónica que dá o seu modelo à morte, intensidade-zero..." A-E, p.435. 
palavras-uivo, refere-se a outro objecto, já não parcial mas completo, ainda que se trate de uma completude ela mesma esquizóide. Assim, o que se encontra em jogo (já no sem-fundo) é uma tensão originária entre o Id e o ego, sendo o Id referente aos objectos parciais e o ego ao corpo sem órgãos, a uma concepção do ego no seu estado, por assim dizer, originário enquanto ego esquizóide ou esquizofrênico propriamente dito. Mas se seguirmos a linha segundo a qual Deleuze concebe o desenvolvimento do ego notaremos, primeiro, que este desenvolvimento (nos termos de um "narcisismo primário") pressupõe a mutação dos objectos parciais (os simulacros) em objectos, também parciais, mas de outra natureza inteiramente diferente, objectos que Deleuze conceberá como imagens. Trata-se assim de uma distinção (crucial) entre uma oralidade das profundidades e outra referente à superfície sexual, onde ao invés de introjectar os objectos agressores e destruidores, a criança passa a projectá-los sobre zonas ou superfícies erógenas, relacionando-as com objectos exteriores (o seio, um brinquedo, etc.), eles mesmos parciais, pelo menos na fase pré-genital (autoerótica). No aspecto geral, falamos assim já não de objectos parciais internos, mas do surgimento desta interioridade abissal sobre a superfície do corpo, ela mesma composta de diferentes zonas, onde os próprios objectos parciais internos sofrem uma metamorfose na medida em que são projectados sobre estas zonas, um pouco como se o "nosso corpo sexuado [fosse] primeiro um traje de Arlequim". ${ }^{65}$ Assim, não nos surpreende que Deleuze recorra a uma frase de Simondon para definir o que entende pela constituição de uma superfície física e sexual na fase pré-genital: ao contrário da interioridade abissal das profundidades, ela "põe topologicamente em contacto o espaço interior com o espaço exterior no limite do ser vivo", ${ }^{66}$ como se de uma película se tratasse (neste sentido, as imagens são "peliculares"). ${ }^{67}$

Enfim, perguntar-se-à como se garante esta reorganização (fundamental) da vida psíquica, esta metamorfose dos simulacros em imagens. Voltemos ao alto: o que está na origem desta reorganização é o surgimento de ainda outro objecto, o bom objecto de alto, sendo nos termos deste objecto que as pulsões sexuais são libertadas dos destruidores (na medida em que o ego esquizóide modela-se segundo o amor e a piedade distribuído por esta "voz" ou dimensão acústica referente ao bom objecto do alto), e, enquanto tal, que se garante a própria constituição das zonas erógenas e consequente metamorfose e

65 LS, p.202.

66 Trata-se de uma citação de Simondon que, repetida ao longo da sua filosofia, parece uma fórmula imediata a Deleuze, um pouco se não existisse esforço intelectual de espécie algum da sua parte em actualizá-la no seu pensamento. Na Lógica do sentido, ela surge remetida à superfície física e sexual e, enquanto tal, concebida "psicanalíticamente". cf. LS, p.202.

67 Ao "ligar a sexualidade à constituição das superfícies ou das zonas que as pulsões libidinosas encontram a sua dupla libertação, pelo menos aparente, que se exprime precisamente no auto-erotismo: por um lado, elas destacam-se do modelo alimentar das pulsões de conservação, já que encontram novas fontes nas zonas erógenas e novos objectos nas imagens projectadas sobre essas zonas ... Por outro lado, elas libertam-se do constrangimento das pulsões destruidoras na medida em que se envolvem no trabalho produtivo das superfícies e nas novas relações com estes novos objectos peliculares". LS, p.204. 
projecção de objectos internos parciais sobre estas zonas. Estamos ou, melhor, estaríamos (já que não o analisaremos) em posição considerar como surgem as imagens parentais (na fase genital ou de um narcisimo agora secundário), nos termos das quais se formará o "complexo" propriamente dito. Fiquemos, mais uma vez, pelo aspecto geral, a sucessão de "progressões" do ponto de vista objectal: começamos com os simulacros, que se transformam em imagens, mas só o fazem através de outro objecto, o bom objecto das alturas, que Deleuze definirá como ídolo ${ }^{68}$ se ainda existe uma metamorfose objectal final, é porque, já o vimos, a história não acaba aqui: é que das imagens vamos ao fantas$m a$, sendo mais precisamente nos termos deste objecto que trataremos de conceber a tal relação original intrínseca entre o sentido e o não-sentido e também, veremos, o porquê desta relação definir a condição (agora crítica e clínica) para a gênese do acto de pensar no próprio pensamento.

Por que fantasma? Porque do ponto de vista da própria evolução do complexo, o falo, que definia uma espécie de superinvestimento na fase genital na medida em que organizava zonas ou superfícies erógenas (fase pré-edipiana), traçando uma linha de organização fálica sobre o corpo, deixa com a formação do complexo (ao confundir-se com o traço da castração) de garantir esta organização (fase edipiana). Que seja este o caso é evidente pelo facto, enfim, de se tratar de uma morte por castração, onde o falo, que definia um excesso na fase genital, passa a designar a sua própria falta, ou seja, pela incapacidade por parte da criança de reparar o corpo (castrado) da mãe através da organização (genital) das zonas erógenas sobre o seu próprio corpo (no que resulta também na dissipação das imagens projectadas sobre esta superfície). ${ }^{69}$ É agora ao internalizar a disjunção entre ambas as séries, a primeira, a pré-edipiana (referente às fases pré-genital e genital), onde o falo define um excesso na organização das zonas erógenas (a linha ou traço fálico), e a segunda, já edipiana (referente à formação do complexo), onde o falo designa uma falta, que podemos, em rigor, falar de um fantasma: e isto porque, interiorizando a relação entre ambas as séries, constituindo-se assim tanto como excesso e falta, o falo nada mais é do que a própria disjunção, a espécie de fissura ou fenda que tanto diferencia ambas as séries como as sintetiza sem jamais transcender a sua função disjuntiva. Falamos assim do que Lacan já havia definido como o falo $=x$, ou seja, do objecto ou "elemento paradoxal" que, dividindo-se em si próprio ao longo de duas direcções opostas (no que destrói o bom senso), jamais é identificável ou reconhecível em si mesmo (no que destrói o senso comum),

68 "Eis por que preferimos a palavra simulacro para designar os objectos das profundidades (que já não são "objectos naturais" [atribuiríamos o "naturalismo" à profundidade regulada referente às sínteses profundas do hábito]), assim como o devir que Ihes corresponde e as inversões que os caracterizam. Ídolo, para designar o objecto das alturas e as suas aventuras. Imagem, para designar o que pertence às superfícies parciais corporais, inclusive o problema inicial da sua concordância fálica (a boa intenção)". LS, p.223.

69 "O resultado é castrar a mãe e ser castrado, matar o pai e ser morto, com a transformação da linha fálica em traço da castração e dissipação de todas as imagens [sobre a superfície física] (a mãe-mundo, o pai-deus, o eu-falo)". LS, p.226. 
ainda que não deixe de fazer ressoar ambas as séries, dividindo-as:

Não há por que insistir sobre os caracteres do falo tais como Lacan os destacou em textos célebres. É ele o elemento paradoxal ou o objecto $=\mathrm{x}$, faltando sempre ao seu próprio equilíbrio, excesso e falta ao mesmo tempo, jamais igual, faltando à sua semelhança, à sua própria identidade, à sua própria origem, ao seu próprio lugar, sempre deslocado em relação a si próprio: significante flutuante e significante flutuado, lugar sem ocupante e ocupante sem lugar, casa vazia e objecto supranumerário. ${ }^{70}$

Ou seja, por um lado temos os corpos, a profundidade dos corpos, a superfície física, a maneira em que a criança aprende a falar sobre o seu corpo; por outro lado, temos os estados de coisas com as suas qualidades, tal como a própria proposição (ou uma lógica formal da representação) os pressupõe nas suas dimensões ordinárias, de designação, manifestação e significação. É agora entre ambos estes "lados", este "interior" e este "exterior", que se encontra "uma superfície ideal", "que transcende o interior e o exterior, pois o que ela tem como propriedade topológica é o facto de colocar em contacto o "seu" lado interior e o "seu" lado exterior para desdobrá-los num só lado". ${ }^{71}$ Desta superfície ou lado único dizemos que é equivalente à energia dessexualizada concebida ontologicamente enquanto mínimo comum tanto à interioridade dos corpos como à exterioridade do ser. Assim, é a função, por assim dizer, do fantasma traçar sobre este lado único um "interior" e um "exterior": falamos essencialmente de um objecto que, inscrevendo-se sobre esta superfície (da qual, ainda assim, é inseparável), constitui-se tanto como uma casa vazia no lado de "dentro" da superfície como um ocupante sem casa ou objecto supranumerário no lado de "fora" deste lado único. Falamos, por outras palavras, do fantasma como um elemento paradoxal genético na origem de uma nova organização, desta vez sobre a superfície metafísica. Jamais se transcende a própria energia dessexualizada ou espécie de destrutividade implicada na pulsão de morte deleuziana, ainda que não se deixe de traçar sobre esta energia e, enquanto tal, sobre a superfície metafísica, uma fronteira ou fenda cujo desdobramento será equivalente ao desenvolvimento da própria superfície e da organização que lhe é inerente.

Já não nos custará associar este lado único ao sentido, à sua dimensão irredutível, confirmando assim a aposta da Lógica do sentido numa história sexual da linguagem. Para tal, basta-nos perguntar o que terá o fantasma que ver com a linguagem. E a resposta que Deleuze dá é a que volta ao verbo, ao verbo no infinitivo, ou seja, ao verbo enquan-

70 LS, p.234-35.

71 LS, p. 218. 
to acontecimento puro. ${ }^{72}$ Já no início da Lógica do sentido, distinguia-se o "verdejar da árvore" da qualidade "verde" que se lhe atribui, dizendo que o verdejar, por um lado, não podia pertencer à árvore no seu ser por se tratar de uma criação da linguagem, e, por outro, que mesmo que interior à linguagem, o verdejar (na medida em que insiste ou subsiste na proposição enquanto acontecimento ideal, infinitivo) não se encontra neste interior mas na própria árvore, como um atributo lógico e não ontológico da mesma. Confirmava-se assim o "estatuto complexo do sentido", do "expresso" enquanto produzido pelas próprias proposições, insistindo ou subsistindo nas mesmas, ainda que atribuído aos estados de coisas, atribuição que supõe uma objectividade completamente distinta, lógica e não ontológica, e que pressupõe a tal dimensão extra-ser do ser enquanto película agora metafísica às quais as próprias coisas seriam como que susceptíveis a uma afectabilidade de outra ordem, desta vez em relação aos acontecimentos ideais produzidos pela própria linguagem..$^{73}$ Mas se perguntarmos o que esta complexidade pressupõe, voltamos a falar de um elemento paradoxal, que, do lado das proposições, constitui-se como uma casa vazia, e, do lado dos estados de coisas, como um ocupante sem casa. Voltamos, por outras palavras, a falar do fantasma, do falo objecto $=\mathrm{x}$ : é o fantasma que, traçando uma fenda na superfície, ela mesma um mínimo comum tanto à interioridade dos corpos como à exterioridade do ser, traça a fronteira entre as proposições e os estados de coisas, a fronteira que o verbo pressupõe enquanto acontecimento ideal, infinitivo. É tanto nos termos da última metamorfose objectal $($ falo $=\mathrm{x}$ ) como da energia dessexualizada, neutra e deslocável, que a pulsão de morte liberta como "resultado" do romance de familiar edipiano, que falamos, por um lado, de uma energia ou espécie de "matéria intensiva" que se constitui como mínimo ontológico comum tanto da interioridade dos corpos como da exterioridade do ser, como também, por outro lado, de um elemento paradoxal que, dividindo-se em si próprio nas duas direcções pressupostas pelo referido "mínimo ontológico", traça sobre esta tela ou superfície metafísica a própria fronteira que divide as proposições e os estados de coisas, a nova interioridade e a nova exterioridade assumidas pela complexidade estatutária inerente ao sentido. Estamos agora no interior de uma nova organização da linguagem, já não referente aos corpos, sejam estas as linguagens do esquizofrênico ou da criança que aprende a escrever sobre o seu próprio corpo, mas ao desdobramento da própria linguagem sobre uma nova tela, desta vez metafísica.

Já o sabemos, ainda que optemos aqui por não o abordar no devido detalhe: segundo Deleuze, é Lewis Carroll quem encena privilegiadamente os paradoxos constitutivos deste desdobramento, da linguagem organizada "à superfície". Falamos assim da encenação da própria linguagem ao longo da fronteira onde colidem o sentido e o não-senti-

72 cf. LS, p.221-23.

73 cf. LS, p.22 para o exemplo do "verdejar" do verde e para a complexidade estatutária do sentido ou do expresso. 
do. Ou seja, a linguagem que se desdobra ao longo das "aventuras" do fantasma, do tal elemento paradoxal, não deixará de se constituir como um não-sentido na medida em que o próprio elemento é ele mesmo um não-sentido, a destruição incessante do sentido comum, do bom senso, e isto, como vimos, por se dividir em direcções opostas, faltar à sua própria origem, etc. Mas se se trata, por outro lado, de um não-sentido que opera a doação de sentido, é por supormos o próprio desdobramento da linguagem ao longo da fronteira que ela mesma pressupõe enquanto sua condição genética, a fronteira entre as proposições e os estados de coisas. Mas para chegarmos até este não-sentido na Lógica do sentido, o de superfície, tivemos de começar por pressupor o que Diferença e repetição não assumia de todo: que do ponto de vista do esquizofrênico e da sua linguagem, não existe prolongamento de espécie alguma entre a destruição da imagem do pensamento e as condições críticas para a gênese do acto de pensar no pensamento. Tivemos, por outras palavras, de analisar como a criança aprende a falar sobre o seu próprio corpo, passando pelo pré-sentido de uma voz do alto, pelo complexo da castração edipiano, pelas várias metamorfoses, pulsionais, objectais, e isto para analisar tanto as transmutações a que o não-sentido é sujeito desde do não-sentido do esquizofrênico até ao da menina, onde "Carroll espera a criança", como a transmutação das destrutividades que ambos estes não-sentidos ou extremos pressupõem. Se agora dizemos que o não-sentido de superfície e a espécie de destrutividade que lhe é inerente informa o que se entende pelas condições críticas e clínicas para a gênese do acto de pensar no pensamento, é na medida em que se definiu a psicanálise como psicanálise do sentido, apostando-se tudo nas relações entre sexualidade, linguagem e metafísica. E como nasce o acto de pensar na imanência da destrutividade que contraefectua as pulsões destruidoras do sem-fundo esquizofrênico em pulsão de morte? Ora, nem é preciso que insistamos muito: basta-nos agora associar o próprio pensamento à energia dessexualizada que, projectada sobre uma superfície metafísica, define o tal mínimo ontológico comum tanto à interioridade dos corpos como à exterioridade do ser. O que dizemos, assim, é que enquanto equivalente a esta energia, o pensamento é também equivalente ao próprio desdobramento desta dimensão ontológica. É como se, enfim, o próprio pensamento fosse ele mesmo este mínimo ou matéria intensiva e, enquanto tal, jamais atribuível à identidade lógica eu=eu de um "eu penso" puro. Mas se, ainda assim, é também no interior da linguagem que se pensa, é porque não deixa de ser nos termos do próprio fantasma, que traça a fronteira entre as proposições e os estados de coisas sobre esta superfície, que se engendra o acto de pensar no próprio pensamento. Ou seja, é tanto a própria superfície ou mínimo ontológico como a fenda que se traça sobre esta superfície que informam a concepção de uma espécie de inconsciente do pensamento puro, de uma tela escura, cerebral, que já nada reflecte da "luz natural" que emana da imagem do pensamento; se é deste inconsciente que se começa a pensar, é porque o que se pensa é o próprio fantasma, o desdobramento da linguagem à superfície, 
entre as proposições e os estados de coisas e ao longo da colisão entre o sentido e o não-sentido, sendo agora nos rebordos desta fenda que surgem os tais elementos estruturais de não-sentido, singularidades pré-individuais e impessoais passíveis de operar uma doação de sentido e, enquanto tal, de garantir as condições críticas e clínicas para a criação de Ideias, as diferenciais do próprio pensamento (uma verdadeira criação, portanto).

4.

Exageramos ao afirmar que é só na $13^{\text {a }}$ série da Lógica do sentido que Deleuze formula o projecto crítico e clínico? Pensamos que não, ainda que, olhando para a relação que Deleuze estabelece entre literatura e sintomatologia, talvez se afirme que tanto a dimensão clínico-psiquiátrica como a crítico-literária estejam presentes no seu pensamento antes da Lógica do sentido (um dos casos mais evidentes seria o livro sobre Masoch). ${ }^{74}$ O mesmo talvez se diga das condições críticas para uma verdadeira criação de Diferença e repetição: se estas condições já pressupõem a versão deleuziana da pulsão de morte, e, através desta pulsão, o próprio inconsciente tal como a psicanálise o concebe, como não seriam também clínicas? Ainda que não tenhamos problema algum em admitir que a questão sintomatológica e a sua relação com a literatura já pressuponha o eixo crítico e clínico, ou que as condições críticas para uma verdadeira criação de Diferença e repetição não sejam alheias à questão clínica, não nos parece que Deleuze chegasse ao ponto de dedicar um livro ao problema crítico e clínico se o que se estivesse em jogo nada mais fosse do que um problema sintomatológico, por mais relevantes que sejam os quadros de sintomas criados pelos ditos "clínicos da civilização". ${ }^{75} \mathrm{Ou}$ seja, se não nos parece que a questão crítica e clínica se refira, pelo menos directamente, a como cada um destes diferentes quadros é criado, é porque ela se refere ao conjunto destes quadros enquanto tais: é do ponto de vista de todos os quadros que se formula a problemática crítica e clínica, sendo assim a espécie de sintomatologia pressuposta pela formação de cada quadro só indirectamente o que se entende por crítica e clínica. Consideremos dois exemplos, centrais à nossa análise: o da linguagem do esquizofrênico e o da linguagem de superfície. Não deixamos de identificar o eixo crítico e clínico na formação de cada um destes quadros: no que se refere à linguagem de superfície, encontramos o aspecto clínico-psiquiátrico na pulsão de morte, ela mesma referente à formação do complexo de Édipo, à dessexualização do inconsciente, à projecção da energia dessexualizada sobre uma superfície ou tela metafísica, à concepção de uma destrutividade que contraefectua a destrutividade do sem-fundo, transmutando-a, etc. Mas encontramos também o aspecto crítico-literário em Blanchot, com as duas figuras ou aspectos da morte, a relação do morrer impessoal com

74 Cf. DELEUZE, Gilles. Sacher-Masoch: o frio e o cruel. Rio de Janeiro: Zahar, 2009.

75 "Os clínicos que sabem renovar um quadro sintomatológico criam uma obra de arte; inversamente, os artistas são clínicos, mas clínicos da civilização". LS, p.244. 
a espécie de transcendência (em relação aos corpos e aos estados de coisas) que Deleuze atribui ao acontecimento e à forma do tempo vazio, que atribui também à libertação de singularidades impessoais e pré-individuais do sem-fundo esquizofrênico dos corpos, enfim, a relação deste morrer com o próprio paradoxo constitutivo do sentido, assente numa relação original entre o sentido e o não-sentido, relação esta que nos leva a Carroll mas também a Lacan, e por aí fora... Com a linguagem do esquizofrênico, falamos do aspecto crítico-literário nos termos da tentativa antigramatical de Artaud contra Carroll, da extraordinária análise de Deleuze e da importância nesta análise de Wolfson e o seu "procedimento", enquanto que, em relação ao aspecto clínico-psiquiátrico, da maneira em que, pelo menos na Lógica do sentido, Deleuze insiste em adaptar uma concepção da profundidade esquizofrênica dos corpos ao teatro de terror "inesquecivelmente" pintado por Klein, revendo o que precisava ser revisto para fazê-lo. Confirma-se assim o que já anunciamos: a presença do eixo crítico e clínico na formação de cada um destes "quadros". Mas se ainda assim insistimos que o projecto crítico e clínico de Deleuze não se refere ao eixo crítico e clínico enquanto remetido a cada um destes quadros, e sim a um problema distinto, o que queremos dizer com isso é que a problemática central deste projecto é definida só no momento em que Deleuze passa a supor uma diferença de natureza entre a linguagem do esquizofrênico e a linguagem de superfície. Ou seja, o que é propriamente "crítico e clínico" não é tanto a maneira em que a própria formação de diferentes quadros pressupõe o cruzamento incessante dos aspectos crítico-literário e clínico-psiquiátrico, mas o problema do tal deslize inicialmente imperceptível de um não-sentido noutro (o aspecto crítico) e das diferentes destrutividades pressupostas por cada um destes não-sentidos (o aspecto clínico). Assim, o problema crítico e clínico é agora informado primeiramente pela linguagem do esquizofrênico, sendo a partir desta linguagem e do desabamento sofrido pelo esquizofrênico, que Deleuze proporá uma "psicanálise do sentido", ou seja, a organização geográfica ou topológica de todos estes quadros enquanto "países diferentes" que compõem tanto uma concepção geral do inconsciente como também a análise dinâmica referente às sucessivas metamorfoses que o próprio inconsciente incorre (tanto do ponto de vista das "progressões" como das "regressões") entre o sem-fundo esquizofrênico e a constituição de uma superfície metafísica.

Seja como for, o aspecto que realmente nos interessa nem tem tanto que ver com a distinção que acabamos de expor, entre a questão crítica e clínica enquanto remetida à questão sintomatológica e esta mesma questão enquanto formulada nos termos da diferença de natureza entre as linguagens do esquizofrênico e de superfície. O que nos interessa é a maneira em que a formulação do problema crítico e clínico, tal como aparece na $13^{\text {a }}$ série da Lógica do sentido, ricocheteia no próprio projecto crítico e ontológico de Diferença e repetição. Se já não se afirmará na Lógica do sentido que a destruição da imagem do pensamento se prolonga através de uma mudança de orientação simples 
que desemboca nas condições críticas para a gênese do acto de pensar no pensamento, é porque, enquanto concebida nos termos da destruição sofrida pelo esquizofrênico, o movimento de destruição vai muito além do limiar que Diferença e repetição propunha como o nível diferencial crítico para uma verdadeira criação. É nos termos do confronto entre Artaud e Carroll que Deleuze admite que quem nos dá a verdadeira destruição da imagem do pensamento é o esquizofrênico; que tratando-se de uma destruição primária em relação à de superfície, ou seja, uma destrutividade que terá de ser contraefectuada numa destrutividade de outra ordem, desta vez de superfície e referente à pulsão de morte, que o que já não se poderá admitir é o que Diferença e repetição admite: que o exercício transcendente das faculdades e a destruição da imagem do pensamento que pressupõe garantem as condições críticas para a gênese do acto de pensar no pensamento. O que assumimos, por outras palavras, são dois exercícios transcendentes distintos, ainda que um (o de superfície) se encontre no interior do outro (o do esquizofrênico), e, por isso mesmo, tanto um como o outro interiores ao que se concebe como a destruição da imagem do pensamento em termos gerais. É como se fosse o "empirismo superior" de Deleuze que abrisse, a partir da $13^{\text {a }}$ série, um capítulo bem mais aterrador. O que jamais se admitirá nos termos de um exercício transcendente esquizofrênico das faculdades, é a associação directa que Deleuze estabelece em Diferença e repetição entre sublimação e a destrutividade do esquizofrênico: segundo a insistência da Lógica do sentido, é mais precisamente a destrutividade de superfície e implicada na pulsão de morte que, contraefectuando o movimento de destruição esquizofrênico, está na origem de uma sublimação; ou seja, e ao contrário do que se assume em Diferença e repetição, onde a pulsão de morte não é pensada sobre incidindo sobre as pulsões destruidoras do sem-fundo esquizofrênico, na Lógica do sentido contraefectuar é sublimar, é, enfim, transmutar destrutividades, não-sentidos, o que só confirma, mais uma vez, que na Lógica do sentido Deleuze jamais passaria com a velocidade que o fez em Diferença e repetição de Kant a Artaud. É justamente a libertação da energia dessexualizada da profundidade esquizofrênica dos corpos que se encontra em jogo para Deleuze na Lógica do sentido, sendo esta energia equivalente à superfície metafísica na medida em que constitui a sua "matéria intensiva". Mas o que assim também se liberta, agora do ponto de vista objectal, é o fantasma, ou seja, o simulacro do sem-fundo esquizofrênico dos corpos enquanto elemento paradoxal genético que passará - agora nos termos de um processo de simbolização ${ }^{76}$ - a ser investido pela energia des-

76 "Chamamos de sublimação a operação pela qual o traçado da castração torna-se linha do pensamento, e também a operação pela qual a superfície sexual e o resto se projectam na superfície do pensamento. Chamamos de simbolização a operação pela qual o pensamento reinveste usando a sua própria energia tudo o que acontece e projecta-se sobre a sua superfície". É de notar também que este "reinvestimento" ou processo de simbolização equivale a uma espécie ressexualização tanto em Diferença e repetição como na Lógica do sentido, ressexualização esta cujo exemplo privilegiado Deleuze encontra no masoquismo. Em Diferença e repetição: "Trata-se da dessexualização nesta terceira síntese, na medida em que ela inibe a aplicação do princípio de prazer como ideia directriz e prévia, para proceder em seguida a uma ressexualização em que o prazer só investe um pensamento puro e frio, apático e gelado". DR, p.204. E na Lógica 
sexualizada ou sublimada ao longo da fronteira onde o sentido e o não-sentido colidem: é ao investir o fantasma, objecto indeterminado e paradoxal (objecto $=\mathrm{x}$ ), e que circula sobre a própria superfície, dividindo-se a si próprio em direcções opostas, faltando ao seu lugar, à sua própria origem, etc., que o próprio acto de pensar nascerá no pensamento, nas margens ou redobros da própria fenda que o movimento do fantasma traça sobre a tela metafísica e, enquanto tal, no interior da ressonância ou das sínteses disjuntivas que o fantasma opera entre séries independentes (significantes e significadas). Falamos assim de um pensamento sem imagem constituído, como o queria Diferença e repetição, na imanência do movimento que destrói a imagem do pensamento, mas, mais uma vez, trata-se agora de uma destruição no interior de outra, bem mais abissal, a do esquizofrênico e cuja "exemplaridade" se refere agora a um exercício transcendente ou "empirismo superior" informado por um abismo esquizofrênico dos corpos.

É verdade que tudo se complica, não o desmentiremos, mas complica-se, a nosso ver, extraordinariamente: é agora o próprio projecto crítico e ontológico de Diferença e repetição que opera no interior da imanência esquizofrênica, do movimento de destruição informado pela esquizofrenia. Insistamos no aspecto central à nossa abordagem, nem que seja para reforçar o que nos parece ter sido tão frequentemente negligenciado: imanência é destruição, é estar no lado de Dentro de um movimento abissal de destruição que varre a imagem do pensamento. Na medida em que este movimento pressupõe um exercício transcendente das faculdades, o que assumimos, paradoxalmente, é o seguinte: que enquanto concebido nos termos do movimento de destruição atrelado a este exercício, $a$ imanência é ela mesma transcendente. Claro, não se trata de uma transcendência clássica, mas a transcendência que subverte o empírico no seu domínio. Ou seja, o exercício transcendente jamais transcende o empírico propriamente dito, mas funciona no seu interior, um pouco como se, nos termos de um "empirismo superior”, fosse o domínio do empírico (inclusive o radical, do "hábito profundo") que pudesse ser subvertido ao longo de dimensões ontológicas distintas da do alto, tanto em profundidade como à superfície. No que se refere às profundidades, são dois os casos que pressupõem esta espécie de empirismo, o "superior": o devir-louco das profundidades tal como é abordado por Deleuze através da análise do simulacro na filosofia antiga, mas também este devir-louco enquanto concebido mais especificamente nos termos do esquizofrênico, de um sem-fundo esquizofrênico dos corpos, onde o próprio empirismo superior de Deleuze ganha uma nova vida ao definir um conjunto de novos problemas. Por outro lado, ainda que falemos de "transcendência", da subversão do empírico no seu próprio domínio, o que ainda não associamos a esta transcendência é justamente o que Deleuze entende por “metafísica”. E isto pelo se-

do sentido: "Uma energia dessexualizada investe ou reinveste um objecto de interesse sexual enquanto tal - e ressexualiza-se assim de um novo modo. Este é o mecanismo mais geral da perversão, na condição que seja distinguida como arte de superfície e a subversão como técnica da profundidade". LS, p.250. 
guinte: estamos ainda na profundidade dos corpos; ainda que o movimento de destruição suponha a transcendência do empírico, não deixa de ser em profundidade, no corpo, que se subverte o empírico no seu próprio domínio. Ou seja, para falarmos de "metafísica" é preciso que criemos o espaço de dentro e o espaço de fora de uma dimensão única, a da superfície ou do "espelho", a dimensão única que transcende duplamente e ao mesmo tempo tanto a profundidade dos corpos como os estados de coisas. Trata-se agora de um novo entendimento de transcendência, propriamente "metafísico". Jamais abandonamos o primeiro sentido de transcendência, referente ao movimento de destruição, à imanência que é estar no Lado de Dentro deste movimento, enfim, o que jamais abandonamos é a profundidade dos corpos, o sem-fundo esquizofrênico... Mas o que define agora uma transcendência propriamente "metafísica" é a superfície que se constitui sobre o movimento de destruição, sobre ou à superficie da própria imanência. Mais uma vez, não se trata da metafísica tradicional ou dogmática, ela mesma dependente da imagem do pensamento e a sua "luz natural": não pressupomos de maneira alguma a dimensão do alto. Se vamos "além do empírico", só o fazemos pelo empírico incluir em si um Dentro mais interior do que qualquer interioridade; é agora deste interior, deste Dentro, ou seja, na imanência do próprio movimento de destruição, que teremos de construir um Fora mais exterior do que qualquer exterioridade, ele mesmo definido nos termos da constituição de uma nova divisão entre o interior e exterior, mas desta vez à superficie do próprio movimento de destruição e da imanência enquanto equivalente a este movimento. É como se o pensamento se movesse agora ao longo de diferentes movimentos, o vertical que tanto afunda como define o movimento na imanência do qual se terá de "subir", como também o horizontal, desta vez à superfície, o movimento que, segundo Deleuze na Lógica do sentido, mas também em Diferença e repetição, é definido pelo movimento do fantasma que traça uma fenda numa superfície metafísica ela mesma constituída sobre o movimento de destruição, à superfície da própria imanência. Como ir do sem-fundo esquizofrênico à superfície? Como investir a própria superfície metafísica enquanto campo transcendental, a espécie de "transcendental metafísico" que, como insiste Deleuze repetidamente, jamais se assemelhará ao empírico, duplicando-o, e isto por se referir a um "espelho" de outra ordem, que tanto espelha a profundidade dos corpos quanto os estados coisas ao longo de uma superfície única que afirma o interior e o exterior agora num só lado? Tratam-se das perguntas centrais da abordagem filosófica que Deleuze define como "empirismo transcendental", e, enquanto tais, à sua filosofia como um todo. Mas o que queríamos realçar era o seguinte: os dois sentidos de "transcendência", o primeiro referente ao movimento de destruição ou de imanência que transcende o empírico em profundidade; e o segundo, agora propriamente "metafísico", mas que só o é realmente na medida em que constitui ou constrói uma superfície sobre o próprio movimento de destruição, à superfície da própria imanência enquanto equivalente a este movimento. 
Por que a Lógica do sentido não atribui ao corpo sem órgãos, ao pólo da língua estrangeira do esquizofrênico, o vislumbre sequer do que definiríamos como a "possibilidade de metafísica”, de uma fronteira entre os corpos e os estados de coisas, enfim, da constituição de uma superfície metafísica sobre o movimento de destruição esquizofrênico? Por que insiste a Lógica do sentido na transmutação de destruições, de não-sentidos, enfim, na destrutividade da pulsão de morte, que contraefectua as pulsões destruidoras do sem-fundo esquizofrênico, e isto tudo para garantir a espécie de destrutividade na imanência da qual seria agora possível construir uma superfície metafísica sobre o próprio movimento de destruição? Simplesmente, porque a aposta de Deleuze é ainda a de uma concepção de "vida" informada essencialmente pela sexualidade: é esta aposta que aprisiona o esquizofrênico no que o Anti-Édipo define como o "sistema repressão-recalcamento edipiano", ${ }^{77}$ onde se assume que o esquizofrênico, a sua linguagem e o movimento de destruição que sofre, jamais garantirão, por si mesmos, as condições críticas e clínicas para a gênese do sentido, para o começo do acto de pensar no pensamento, enfim, para a construção de uma superfície metafísica constituída sobre o movimento de destruição e de imanência esquizofrênico. É Dentro e não sobre este movimento, o da própria imanência, que Deleuze condena o esquizofrênico a permanecer, ainda que não deixe de afirmar na Lógica do sentido, curiosamente, que não daria uma página de Artaud por todas as de Carroll. ${ }^{78}$ Enfim, já o sabemos, é justamente esta aposta que será abandonada a partir de Capitalismo e Esquizofrenia e do encontro com Guattari. ${ }^{79}$ Ainda assim, não deixaremos de insistir que uma abordagem detalhada deste abandono terá de começar um pouco antes, na passagem de Diferença e repetição à Lógica do sentido e com a maneira em que o esquizofrênico, Artaud, estremece o próprio pensamento de Deleuze, estando assim na origem de uma série de novos acontecimentos na sua filosofia: a nova concepção de imanência assente na concepção de uma destrutividade envolvida noutra, de um não-sentido noutro, a gênese do projecto crítico e clínico, e, finalmente, a nova teoria do inconsciente que, apostando tudo na tríade sexualidade/linguagem/metafísica, reorienta a própria psicanálise na direcção de uma psicanálise do sentido.

77 cf. A-E, p.182-184.

78 "Por todo Carroll, não daríamos uma página de Artaud". LS, p.93.

79 É Deleuze quem o admite numa entrevista a Arnaud Villani: "Esse era o caso [a aposta na sexualidade] até à Lógica do sentido, onde ainda existia uma relação determinável entre sexualidade e metafísica. Depois disso, a sexualidade pareceu-me uma abstração mal-fundada". "Response to a Series of Questions", Collapse, vol. III. Londres: Urbanomic, 2007 - a tradução é nossa. 


\section{REFERÊNCIAS BIBLIOGRÁFICAS:}

ARTAUD, Artaud. Eu, Antonin Artaud. Tr. Aníbal Fernandes. Lisboa: Assírio \& Alvim, 2007. . Oeuvres. Paris: Gallimard, 2004.

DELEUZE, Gilles. Crítica e clínica. Tr. Peter Pál Pelbart. São Paulo: 34, 1997. . Diferença e repetição. Tr. Luiz Orlandi e Roberto Machado. Lisboa: Relógio d'Água, 2000.

. Lógica do sentido. Tr. Luiz Roberto Salinas Fortes. São Paulo: Perspectiva, 2006.

. Sacher-Masoch: o frio e o cruel. Tr. Jorge Bastos. Rio de Janeiro: Zahar, 2009.

DELEUZE-GUATTARI. O Anti-Édipo. Tr. Luiz Orlandi. São Paulo: 34, 2010.

GIL, José. O imperceptivel devir da imanência - sobre a filosofia de Deleuze. Lisboa: Relógio d'Água, 2008. 